\title{
Radiation-Grafted Anion-Exchange Membrane for Fuel Cell and Electrolyzer Applications: A Mini Review
}

\author{
Kean Long Lim ${ }^{1, *(\mathbb{D}}$, Chun Yik Wong ${ }^{1}$, Wai Yin Wong ${ }^{1}{ }^{\mathbb{D}}$, Kee Shyuan Loh ${ }^{1}$, Sarala Selambakkannu ${ }^{2}{ }^{\mathbb{D}}$, \\ Nor Azillah Fatimah Othman ${ }^{2}$ and Hsiharng Yang ${ }^{3, *(\mathbb{D}}$ \\ 1 Fuel Cell Institute, Universiti Kebangsaan Malaysia, Bangi 43600, Malaysia; nickwcy72@gmail.com (C.Y.W.); \\ waiyin.wong@ukm.edu.my (W.Y.W.); ksloh@ukm.edu.my (K.S.L.) \\ 2 Radiation Processing Technology Division, Malaysia Nuclear Agency, Kajang 43000, Malaysia; \\ sarala@nuclearmalaysia.gov.my (S.S.); azillah@nm.gov.my (N.A.F.O.) \\ 3 Graduate Institute of Precision Engineering and Innovation and Development Center of Sustainable \\ Agriculture (IDCSA), National Chung Hsing University, 145 Xingda Road, South District, \\ Taichung City 402, Taiwan \\ * Correspondence: kllim@ukm.edu.my (K.L.L.); hsiharng@dragon.nchu.edu.tw (H.Y.); \\ Tel.: +60-3-8911-8494 (K.L.L.); +886-4-22873629 (H.Y.)
}

check for updates

Citation: Lim, K.L.; Wong, C.Y.;

Wong, W.Y.; Loh, K.S.;

Selambakkannu, S.; Othman, N.A.F.;

Yang, H. Radiation-Grafted

Anion-Exchange Membrane for Fuel Cell and Electrolyzer Applications: A Mini Review. Membranes 2021, 11, 397. https://doi.org/10.3390/

membranes11060397

Academic Editor: Jin-Soo Park

Received: 1 February 2021

Accepted: 24 May 2021

Published: 27 May 2021

Publisher's Note: MDPI stays neutral with regard to jurisdictional claims in published maps and institutional affiliations.

Copyright: (c) 2021 by the authors. Licensee MDPI, Basel, Switzerland. This article is an open access article distributed under the terms and conditions of the Creative Commons Attribution (CC BY) license (https:/ / creativecommons.org/licenses/by/ $4.0 /)$.

\begin{abstract}
This review discusses the roles of anion exchange membrane (AEM) as a solid-state electrolyte in fuel cell and electrolyzer applications. It highlights the advancement of existing fabrication methods and emphasizes the importance of radiation grafting methods in improving the properties of AEM. The development of AEM has been focused on the improvement of its physicochemical properties, including ionic conductivity, ion exchange capacity, water uptake, swelling ratio, etc., and its thermo-mechano-chemical stability in high-pH and high-temperature conditions. Generally, the AEM radiation grafting processes are considered green synthesis because they are usually performed at room temperature and practically eliminated the use of catalysts and toxic solvents, yet the final products are homogeneous and high quality. The radiation grafting technique is capable of modifying the hydrophilic and hydrophobic domains to control the ionic properties of membrane as well as its water uptake and swelling ratio without scarifying its mechanical properties. Researchers also showed that the chemical stability of AEMs can be improved by grafting spacers onto base polymers. The effects of irradiation dose and dose rate on the performance of AEM were discussed. The long-term stability of membrane in alkaline solutions remains the main challenge to commercial use.
\end{abstract}

Keywords: grafting; irradiation; green hydrogen; alkaline fuel cell; alkaline water electrolysis

\section{Overview of Anion Exchange Membrane for Fuel Cell (AEMFC) and Electrolysis Cell (AEMEC) Applications}

The alkaline fuel cell was among the first commercial hydrogen-oxygen fuel cells invented in the 20th century, and it was used in the NASA Apollo space mission program in the 1960s. The reverse reaction of this hydrogen-oxygen combination process is electrolysis, and the alkaline electrolysis cell is one of the reliable and mature water splitting technologies used to produce hydrogen on a large scale. Both technologies are viewed as a sustainable solution to bridge the renewable energy sources to end-users that use green hydrogen as the carbon-free energy carrier. While the proton exchange membrane (PEM) fuel cell has gained more popularity [1-5] than the alkaline fuel cell in low-temperature applications, alkaline electrolyzer remains widely deployed for largescale hydrogen production from renewable energy. Both these alkaline technologies are relatively cost effective because non-precious metal electrocatalysts show favorable, stable and efficient performance towards oxygen reduction (for fuel cell) as well as evolution (for electrolyzer) reactions, which are attained in an alkaline environment. Nevertheless, 
both technologies use strong alkaline aqueous solution (i.e., $\mathrm{KOH}$ ) as an electrolyte that unfortunately can react with carbon dioxide in the air to produce insoluble precipitates (i.e., $\mathrm{K}_{2} \mathrm{CO}_{3}$ ), leading to the blockage of catalyst active sites and porous separator as well as the reduction of hydroxyl ions in anolyte, which eventually reduce the overall performance of the devices. In addition, the alkaline fuel cell and electrolyzer with liquid electrolyte [6] are inherently troublesome to shut down/start up, prone to leaking, have a high concentration gradient, and require consistent and stable output conditions. Leveraging on the knowledge of proton exchange membrane (PEM), solid-state anion exchange membrane (AEM), which offers the similar advantages of alkaline liquid fuel cell/electrolyzer, has been proposed as the replacement for liquid electrolyte. With the recent announcement of the Green Deal by the European Union and gaining interest of green hydrogen production from water electrolysis, AEM electrolysis has been viewed as a potential technology that could reduce the hydrogen production cost significantly to the targeted price of USD $4 / \mathrm{kg}$ $\mathrm{H}_{2}[7,8]$.

Merle et al. [9] have classified the AEMs into three categories: heterogenous membranes, interpenetrating polymer networks and homogeneous membranes. Heterogenous membrane can be prepared by embedding anion exchange material in an inert compound (either hydroxide salt or inorganic nanoparticles), whereas interpenetrating polymer networks is an amalgamation of two polymers in the form of a network, where both polymers are either partially or fully crosslinked. Most AEMs are homogeneous membranes and typically can be prepared via direct polymerization and crosslinking or the chemical modification of polymers by irradiation, grafting or chemical reactions. Homogeneous anion exchange membrane is defined by a semi-permeable membrane that consists of positively charged cation head groups that are immobilized in the polymer backbone that allow for the creation of conduction channels for the mobile, negatively charged anions to transport through the membrane [10]. The immobilization of cation head groups also limits their reaction and contact with carbon dioxide to reduce and prevent the formation of carbonate precipitates [11]. The polymer backbones of AEM are usually based on polysulfone, poly(arylene ether), poly(phenylene), polystyrene, polypropylene, poly(ether sulfone), poly(phenylene oxide), polyolefin, poly(arylene piperidinium) and poly(biphenyl alkylene) $[8,12]$. In comparison to PEM, the performance of AEM is admittedly lower due to the higher ion mobility in $\mathrm{H}^{+}$(4.76) compared to $\mathrm{OH}^{-}$(2.69) [13]. In an anion exchange membrane fuel cell (AEMFC), oxygen is reduced at the cathode side and to produce hydroxide $\left(\mathrm{OH}^{-}\right)$ions and electrons, where hydroxide ions transport through the AEM towards the anode side and subsequently react with hydrogen to produce water, whereas the electrons travel through the external circuit to produce electricity current. Equations (1)-(3) describe the electrochemical reactions at the cathode side, anode side and overall reaction, respectively.

Cathode:

$$
\mathrm{O}_{2}+2 \mathrm{H}_{2} \mathrm{O}+4 \mathrm{e}^{-} \rightarrow 4 \mathrm{OH}^{-},
$$

Anode:

$$
2 \mathrm{H}_{2}+4 \mathrm{OH}^{-} \rightarrow 4 \mathrm{H}_{2} \mathrm{O}+4 \mathrm{e}^{-},
$$

Overall:

$$
2 \mathrm{H}_{2}+\mathrm{O}_{2} \rightarrow 2 \mathrm{H}_{2} \mathrm{O},
$$

On the other hand, the anion exchange membrane electrolysis cell (AEMEC) uses electricity to split the water molecules into hydrogen gas and hydroxide ions at the cathode side, and the hydroxide ions transport through the membrane and eventually oxidize to produce oxygen gas and water, as shown in Equations (4)-(6). Ideally, water should be fed and consumed at the cathode, but many reported systems still feed hydroxide-ion-rich alkaline solutions to the cathode.

Cathode:

$$
4 \mathrm{H}_{2} \mathrm{O}+4 \mathrm{e}^{-} \rightarrow 2 \mathrm{H}_{2}+4 \mathrm{OH}^{-},
$$


Anode:

$$
4 \mathrm{OH}^{-} \rightarrow \mathrm{O}_{2}+2 \mathrm{H}_{2} \mathrm{O}+4 \mathrm{e}^{-},
$$

Overall:

$$
2 \mathrm{H}_{2} \mathrm{O} \rightarrow 2 \mathrm{H}_{2}+\mathrm{O}_{2},
$$

While the efficiency of both electricity generation and water splitting depends highly on the performance of overall membrane electrode assembly (MEA) [14], which includes the catalyst, gas diffusion layers and electrolyte membrane, the mobility of $\mathrm{OH}^{-}$in the membrane plays the most essential role in dictating the overall fuel cell/electrolysis cell performance. In addition to high anion conductivity, high thermo-mechanical and chemical stability properties of AEM are also highly sought after. Selection of cationic head groups, morphology design of membrane, product scalability, cost of raw materials and fabrication methods are factors to be considered and optimized to meet the commercial viability criteria [15].

\section{Modification of Anion-Exchange Membrane}

In the past, a conventional process "polymerization-chloromethylation-amination" is usually employed to prepare AEMs [16]. This process is relatively mature and provides good performance for the membrane. However, the chloromethylation agent (chloromethyl ether) being used over that time had proven to be carcinogenic and hazardous [17]. Thereof, the alternative in the co-polymerization of vinylbenzyl chloride (VBC) with divinylbenzene (DVB), the grafting of VBC or vinylpyridine onto polymer, and the copolymerization of epoxy acrylates such as glycidyl methacrylate (GMA) have been reported as the halomethylsubstituted monomers to replace the usage of chloromethyl ether [18]. Aside from that, a variety of cationic functional groups have been proposed for AEM applications such as quaternary ammonium, imidazolium, pyridinium, guanidinium, phosphonium and sulfonium [19-26]. Quaternary ammonium ions have been traditionally used as the cation head group, but they are susceptible to chemical degradation via (i) Hofmann elimination, (ii) nucleophilic substitution and (iii) ylide formation [27]. One of the most important criteria in the selection of cation functional group is centered on its chemical stability under alkaline conditions. Hence, other nitrogen-containing cations (imidazolium, pyridinium and guanidinium) and nitrogen-free cations (phosphonium and sulfonium) head groups are also considered for AEM applications. Though a huge number of studies have been conducted in relation to AEMs, there are challenges in practical applications that remain to be solved, for instance, the low ionic conductivity of AEMs and low chemical stability of cationic functional groups as well as the polymer backbone in alkaline media [28-30]. Studies have shown that different fabrication methods even on the same polymer type could result in different properties. According to Maurya et al. [18], the final properties of the AEMs are intimately linked to the methods and materials used in fabricating an AEM. By integrating different polymer fabrication processes and altering the morphology of polymers, the performance and characteristics of AEM can be engineered. Generally, AEMs are prepared through three main steps, including the polymerization of halomethyl-substituted monomers, film casting and quaternization to create the cation head group on the polymeric film. The formation of the film is normally performed via solution casting or the sol-gel technique. Meanwhile, on the attempt to improve the thermo-mechanical, chemical stability, and ion conductivity properties of AEMs, various modification methods have been investigated by employing different polymers and reagents. Among the most commonly reported methods are direct copolymerization, plasma polymerization, the pore-filling method, and supported composite AEMs [18,31-33]. Copolymerization, which involves the use of halomethyl-substituted monomers as copolymer, which is required to serve as the site for quaternization in the subsequent process, is one of the crucial methods to create the anions' transport sites on the membrane. For AEMs, the grafted co-polymerization technique, where the side chain grafts of the co-polymer are covalently attached to the polymer main chain, is more favorable compared to blocked copolymerization to increase the active 
sites for anion transport. Radiation-grafted copolymerization has emerged as the preferred technique, owing to its ease in controlling the degree of grafting, its ability to scale-up and the fact that it can minimize the residues left on the membrane during the process. This section will compare the different modification methods towards several properties of AEMs, including the ionic conductivity summarized in Table 1. Radiation-grafted AEMs will be highlighted based on their superior properties compared to other methods.

\subsection{AEM Prepared via Solution Casting}

Solution casting is the conventional method to fabricate AEM, which generally applies to soluble polymers, their blends, or copolymers [18]. In technical terms, this method comes with a four-step procedure, namely, the dissolution of polymer, introduction of the cation functional group via chloromethylation, polymer solution casting and quaternization. For instance, an alkalized poly(ether imide) (A-PEI) was synthesized by Oh et al. [34] in accordance to the steps given in Figure 1. The chemical structures of the A-PEI were confirmed by FTIR and NMR, which called the successful grafting of the ammonium group on the backbone of polymer. Based on the results obtained, the A-PEI membrane with a ratio between tin chloride and chloromethyl methyl ether (CMME) of 1:80 has shown the highest performance in IEC and hydroxide ionic conductivity at $1.23 \mathrm{meq} \mathrm{g}^{-1}$ and $44.2 \mathrm{mS} \mathrm{cm}^{-1}$, respectively. Parrondo et al. [35] demonstrated a novel AEM, synthesized by Friedel-Crafts acylation of 6-bromo-1-hexanoyl chloride on poly(phenylene oxide) (C6-PPO) followed by alkalization with trimethylamine (TMA). Interestingly, their results present neither a sign of improvement over the performance (IEC reported at $1.8 \mathrm{meq} \mathrm{g}^{-1}$ compared to membrane without quaternization of $1.7 \mathrm{meq} \mathrm{g}^{-1}$ ) nor its chemical stability in alkaline conditions, which is against their hypothesis regarding the potential of hexyl spacers of C6-PPO in stabilizing the AEM. Such an outcome is unusual because having spacer provides an advantage in side-chain flexibility, and subsequently enhances the anion conduction. This can be seen from the work of Zhu et al. [36], whereby an AEM was synthesized by incorporating rotatable ethylene oxide spacers into imidazolium-containing cationic side-chains. The PPO-based imidazolium AEM demonstrates a unique character whereby the facile rotation of $\mathrm{C}-\mathrm{O}-\mathrm{C}$ ether bonds contributes to the reduction in glass transition temperature and promotes the ion transportation. The hydroxide conductivity and IEC were reported at $45 \mathrm{mS} \mathrm{cm}^{-1}$ and $2.1 \mathrm{meq}^{-1}$, respectively, while the single cell AEMFC performance yielded a value of $437 \mathrm{~mW} \mathrm{~cm}^{-2}$ at $65^{\circ} \mathrm{C}$.

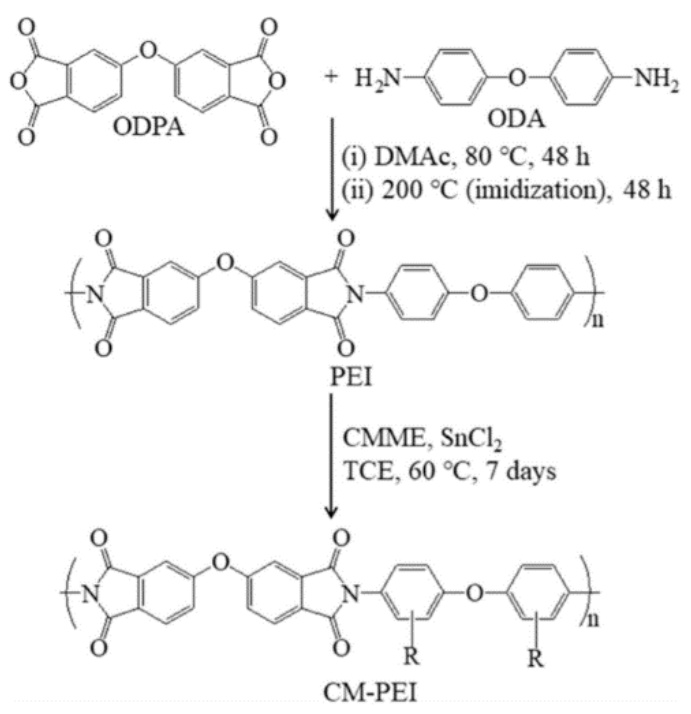

Figure 1. Synthesis and chemical structures of PEI and chloromethylated-PEI (CMPEI). Reprinted with permission from [34]. Copyright Elsevier, 2019. 
Table 1. Properties of anion exchange membrane (AEM) with different preparation methods.

\begin{tabular}{|c|c|c|c|c|c|c|c|c|c|}
\hline $\begin{array}{l}\text { Modification } \\
\text { Method }\end{array}$ & Polymer & $\begin{array}{c}\text { Reagent(s) for Cationic Head } \\
\text { Group }\end{array}$ & $\begin{array}{l}\text { Water Uptake } \\
(\%)\end{array}$ & $\begin{array}{l}\text { Swelling } \\
\text { Ratio (\%) }\end{array}$ & $\begin{array}{c}\text { Tensile } \\
\text { Strength } \\
(\mathrm{MPa})\end{array}$ & $\begin{array}{c}\text { IEC } \\
\left(\text { meq }^{-1}\right)\end{array}$ & $\begin{array}{c}\text { Ionic } \\
\text { Conductivity } \\
\left(\mathrm{mS} \mathrm{cm} \mathrm{cm}^{-1}\right)\end{array}$ & $\begin{array}{c}\text { Cell } \\
\text { Performance } \\
\left(\mathrm{mW} \mathrm{cm} \mathrm{cm}^{-2}\right)\end{array}$ & Ref. \\
\hline \multirow{8}{*}{$\begin{array}{l}\text { Simple solution } \\
\text { casting without } \\
\text { modification }\end{array}$} & PEI & Trimethylamine (TMA) & 40.3 & 19.2 & 21.5 & 1.23 & $44.2\left(\right.$ at $\left.90^{\circ} \mathrm{C}\right)$ & - & [34] \\
\hline & C6-PPO & TMA & - & - & - & 1.80 & 1.2 (at $25^{\circ} \mathrm{C}$ ) & - & [35] \\
\hline & $\mathrm{PPO}$ & $\begin{array}{l}\text { 1,2-bis(2-(2-methylimidazole) } \\
\text { ethoxy)ethane }\end{array}$ & $\begin{array}{l}150.0(\text { at } \\
\left.60^{\circ} \mathrm{C}\right)\end{array}$ & 18.0 & - & 2.10 & $45.0\left(\right.$ at $\left.60^{\circ} \mathrm{C}\right)$ & $437.0\left(\right.$ at $\left.65^{\circ} \mathrm{C}\right)$ & [36] \\
\hline & $\begin{array}{l}\text { Poly(fluorenyl ether } \\
\text { ketone sulfone) } \\
\text { (PFEKS) }\end{array}$ & $\begin{array}{l}\text { (i) TMA } \\
\text { (ii) 1-methylimidazole (IM) }\end{array}$ & $\begin{array}{l}\text { (i) } 59.0 \\
\text { (ii) } 48.0\end{array}$ & - & - & $\begin{array}{l}\text { (i) } 1.80 \\
\text { (ii) } 1.60\end{array}$ & $\begin{array}{l}\text { (i) } 22.3 \\
\text { (ii) } 17.1\end{array}$ & - & [37] \\
\hline & $\mathrm{PPO}$ & $\begin{array}{c}\text { 1-benzyl-3-methyl-4-butyl- } \\
\text { 1,2,3-triazolium } \\
\text { iodide }\end{array}$ & 128.0 & 35.0 & - & 1.21 & 61.6 & - & [38] \\
\hline & PTFE & $\begin{array}{c}\text { Quaternized } \\
\text { 1,4-diazabicyclo[2.2.2]-octane } \\
\text { (DABCO) }\end{array}$ & 24.0 & 17.0 & 32.0 & - & $51.0\left(\right.$ at $\left.55^{\circ} \mathrm{C}\right)$ & $146\left(\right.$ at $\left.50^{\circ} \mathrm{C}\right)$ & [39] \\
\hline & Polysulfone & DABCO & 122.7 & 12.3 & 24.0 & 1.68 & 0.9 & - & [40] \\
\hline & СРPO/ВРPO & TMA & 137.4 & - & 28.0 & 2.10 & 27.6 & - & [41] \\
\hline \multirow[t]{6}{*}{$\begin{array}{c}\text { Covalent } \\
\text { crosslinking }\end{array}$} & Polysulfone & Quaternary phosphonium & 100.0 & 15.0 & - & 1.23 & $38.0\left(\right.$ at $\left.20^{\circ} \mathrm{C}\right)$ & - & [25] \\
\hline & ETFE & TMA & 11.7 & 0.8 & 55.8 & 1.07 & $15.3\left(\right.$ at $\left.60^{\circ} \mathrm{C}\right)$ & - & [42] \\
\hline & $\begin{array}{c}\text { Ethylene-co- } \\
\text { tetrafluoroethylene } \\
\text { (ETFE) }\end{array}$ & TMA & 64.4 & - & - & 2.11 & $73.5\left(\right.$ at $\left.80^{\circ} \mathrm{C}\right)$ & 48.0 (at $40^{\circ} \mathrm{C}$ ) & [43] \\
\hline & Polysulfone & $\begin{array}{c}\text { N-methyl-pyrrolidinone } \\
\text { (NMP) }\end{array}$ & 22.7 & - & - & 1.33 & - & - & [44] \\
\hline & $\begin{array}{l}\text { Poly(acrylene ether } \\
\text { sulfone) (PSF) }\end{array}$ & TMA & 50.0 & 24.0 & - & 0.73 & 5.5 & - & [45] \\
\hline & PVBC & PVAC & 139.1 & 26.3 & 14.2 & 1.26 & 29.0 & $124.7\left(\right.$ at $\left.40^{\circ} \mathrm{C}\right)$ & [46] \\
\hline
\end{tabular}


Table 1. Cont.

\begin{tabular}{|c|c|c|c|c|c|c|c|c|c|}
\hline $\begin{array}{l}\text { Modification } \\
\text { Method }\end{array}$ & Polymer & $\begin{array}{c}\text { Reagent(s) for Cationic Head } \\
\text { Group }\end{array}$ & $\begin{array}{l}\text { Water Uptake } \\
\text { (\%) }\end{array}$ & $\begin{array}{l}\text { Swelling } \\
\text { Ratio (\%) }\end{array}$ & $\begin{array}{c}\text { Tensile } \\
\text { Strength } \\
(\mathrm{MPa})\end{array}$ & $\begin{array}{c}\text { IEC } \\
\left(\text { meq }^{-1}\right)\end{array}$ & $\begin{array}{c}\text { Ionic } \\
\text { Conductivity } \\
\left(\mathrm{mS} \mathrm{cm}^{-1}\right)\end{array}$ & $\begin{array}{c}\text { Cell } \\
\text { Performance } \\
\left(\mathrm{mW} \mathrm{cm} \mathrm{cm}^{-2}\right)\end{array}$ & Ref. \\
\hline & PVBC & $\mathrm{PPO}-\mathrm{N}_{3}$ & 19.8 & 6.9 & 59.5 & 1.95 & 14.8 (at $\left.20^{\circ} \mathrm{C}\right)$ & $11.0\left(\right.$ at $\left.60^{\circ} \mathrm{C}\right)$ & [47] \\
\hline \multirow[t]{6}{*}{$\begin{array}{l}\text { Composite } \\
\text { membrane with } \\
\text { inorganic fillers }\end{array}$} & $\begin{array}{l}\text { Polysulfone } \\
\text { Filler: } \mathrm{TiO}_{2}\end{array}$ & TMA & 39.0 & - & - & - & $125.2\left(\right.$ at $\left.21^{\circ} \mathrm{C}\right)$ & - & [27] \\
\hline & $\begin{array}{l}\text { Polysulfone } \\
\text { Filler: } \mathrm{ZrO}_{2}\end{array}$ & Triethyl amine (TEA) & 18.3 & - & 28.4 & 0.90 & 14.6 & $250.0\left(\right.$ at $\left.60^{\circ} \mathrm{C}\right)$ & [48] \\
\hline & $\begin{array}{c}\text { Poly(vinyl alcohol) } \\
\text { (PVA) } \\
\text { Filler: } \mathrm{Al}_{2} \mathrm{O}_{3} \\
\end{array}$ & $\mathrm{KOH}$ & - & - & - & - & 0.6 & - & [49] \\
\hline & $\begin{array}{c}\text { PVA } \\
\text { Filler: Bentonite }\end{array}$ & $\mathrm{KOH}$ & 65.0 & - & - & - & 110.0 & - & [50] \\
\hline & $\begin{array}{l}\text { Chitosan/PVA } \\
\text { Filler: GO }\end{array}$ & $\mathrm{NaOH}$ & 138.4 & - & 48.6 & 0.37 & 0.1 & - & [51] \\
\hline & $\begin{array}{l}\text { Fumion }{ }^{\circledR} \\
\text { Filler: GO }\end{array}$ & NMP & 18.4 & - & 2890.6 & 3.16 & $113.2\left(\right.$ at $\left.80^{\circ} \mathrm{C}\right)$ & - & [53] \\
\hline \multirow[t]{4}{*}{ Pore-filling } & $\begin{array}{l}\text { PTFE filled with } \\
\text { poly(DMAEMA-DVB) }\end{array}$ & p-xylene dichloride (XBC) & 19.9 & - & 44.7 & 1.40 & 128.0 & 7.7 (at $60{ }^{\circ} \mathrm{C}$ ) & [54] \\
\hline & PTFE filled with QPPO & TEA & 14.6 & 18.3 & 275.0 & 1.44 & 33.1 & - & [55] \\
\hline & $\begin{array}{l}\text { Poly(styrene) filled } \\
\text { with VBC-DVB }\end{array}$ & TMA & 25.8 & 10.1 & 125.8 & 2.04 & 0.4 & - & [56] \\
\hline & $\begin{array}{l}\text { Polyethylene filled with } \\
\text { VBC-DVB }\end{array}$ & Pyridine & 70.0 & 4.0 & - & 0.95 & - & - & [57] \\
\hline $\begin{array}{c}\text { Conventional } \\
\text { copolymerization }\end{array}$ & $\begin{array}{l}\text { Hyper-branched } \\
\text { PVBC-grafted-VBC }\end{array}$ & TMA & 38.6 & 36.3 & 6.77 & 1.26 & $50.8\left(\right.$ at $\left.30^{\circ} \mathrm{C}\right)$ & - & [58] \\
\hline
\end{tabular}


Table 1. Cont.

\begin{tabular}{|c|c|c|c|c|c|c|c|c|c|}
\hline $\begin{array}{l}\text { Modification } \\
\text { Method }\end{array}$ & Polymer & $\begin{array}{l}\text { Reagent(s) for Cationic Head } \\
\text { Group }\end{array}$ & $\begin{array}{c}\text { Water Uptake } \\
(\%)\end{array}$ & $\begin{array}{l}\text { Swelling } \\
\text { Ratio (\%) }\end{array}$ & $\begin{array}{c}\text { Tensile } \\
\text { Strength } \\
\text { (MPa) }\end{array}$ & $\begin{array}{c}\text { IEC } \\
\left(\text { meq }^{-1}\right)\end{array}$ & $\begin{array}{c}\text { Ionic } \\
\text { Conductivity } \\
\left(\mathrm{mS} \mathrm{cm}^{-1}\right)\end{array}$ & $\begin{array}{c}\text { Cell } \\
\text { Performance } \\
\left(\mathrm{mW} \mathrm{cm} \mathrm{cm}^{-2}\right)\end{array}$ & Ref. \\
\hline & $\begin{array}{l}\text { Polychloromethylstyrene- } \\
b \text {-polycyclooctene- } b \text { - } \\
\text { polychloromethylstyrene } \\
\text { (PCMS- } b \text {-PCOE- } b \\
\text {-PCMS) }\end{array}$ & TMA & 64.7 & 13.6 & 184.5 & 1.83 & $179.0\left(\right.$ at $80^{\circ} \mathrm{C}$ ) & - & [59] \\
\hline & $\begin{array}{c}\text { Quaternized } \\
\text { poly(arylene ether } \\
\text { sulfone) }\end{array}$ & DABCO & $74.1\left(\right.$ at $\left.90^{\circ} \mathrm{C}\right)$ & $\begin{array}{l}29.6(\text { at } \\
\left.90^{\circ} \mathrm{C}\right)\end{array}$ & - & 1.86 & $51.8\left(\right.$ at $\left.90^{\circ} \mathrm{C}\right)$ & $64.0\left(\right.$ at $\left.60^{\circ} \mathrm{C}\right)$ & [60] \\
\hline & $\begin{array}{l}\text { Quaternized chitosan- } \\
\text { polyacrylamide/polystyrene } \\
\text { (QCS-PAM/PS) }\end{array}$ & $\begin{array}{c}\text { (2,3-epoxypropyl) } \\
\text { trimethylammonium } \\
\text { chloride (EPTMAC) }\end{array}$ & 64.5 & 19.0 & 43.9 & 0.93 & $6.0\left(\right.$ at $\left.80^{\circ} \mathrm{C}\right)$ & - & [61] \\
\hline \multirow[t]{10}{*}{$\begin{array}{l}\text { Radiation grafting } \\
\text { copolymerization }\end{array}$} & $\begin{array}{c}\text { Low density } \\
\text { polyethylene-grafted- } \\
\text { VBC } \\
\text { (LDPE-g-VBC) }\end{array}$ & TMA & - & - & - & 2.53 & $85.0\left(\right.$ at $\left.60^{\circ} \mathrm{C}\right)$ & - & [62] \\
\hline & HDPE-g-VBC & TMA & 155.0 & 21.0 & 35.0 & 2.44 & $214.0\left(\right.$ at $\left.80^{\circ} \mathrm{C}\right)$ & $2550.0\left(\right.$ at $\left.80^{\circ} \mathrm{C}\right)$ & [63] \\
\hline & LDPE-g-VBC & TMA & 285.0 & 55.6 & 11.2 & 3.20 & $120.0\left(\right.$ at $\left.70^{\circ} \mathrm{C}\right)$ & $607.8\left(\right.$ at $\left.50^{\circ} \mathrm{C}\right)$ & {$[64]$} \\
\hline & MNVIm/En/St-AEM & 2-methylimidazolium & 128.0 & 23.0 & - & 1.05 & $55.0\left(\right.$ at $\left.80^{\circ} \mathrm{C}\right)$ & - & [65] \\
\hline & ETFE-g-VBC & TMA & 155.4 & - & - & 1.24 & - & $240.0\left(\right.$ at $\left.50^{\circ} \mathrm{C}\right)$ & {$[66]$} \\
\hline & $\begin{array}{c}\text { Polyethylene-grafted- } \\
\text { VBC } \\
\text { (PE-g-VBC) }\end{array}$ & TMA & 13.7 & 14.6 & - & 0.49 & 47.5 (at $90^{\circ} \mathrm{C}$ ) & - & [67] \\
\hline & PE-g-VBC & $\begin{array}{l}\text { 1,1,3,3-tetramethyl-2-n- } \\
\text { butylguanidine } \\
\text { (TMBG) }\end{array}$ & 4.5 & 7.3 & - & 0.33 & 27.7 (at $\left.90^{\circ} \mathrm{C}\right)$ & - & [68] \\
\hline & LDPE-g-VBC & TMA & - & - & - & 2.30 & $90.0\left(\right.$ at $\left.50^{\circ} \mathrm{C}\right)$ & $180 \mathrm{mV}$ & [69] \\
\hline & ETFE-g-VBC & TMA & 40.0 & - & 18.2 & - & $34.0\left(\right.$ at $\left.50^{\circ} \mathrm{C}\right)$ & $2.8\left(\right.$ at $\left.50^{\circ} \mathrm{C}\right)$ & [10] \\
\hline & ETFE-g-VBC & TMA & 57.0 & 32.0 & 27.0 & 2.13 & 68.0 (at $\left.80^{\circ} \mathrm{C}\right)$ & - & [70] \\
\hline
\end{tabular}


Nevertheless, the hydrophilic and rotatable ethylene oxide as spacer has high water affinity due to its tendency to form a hydrogen bond between ether groups and $\mathrm{H}_{2} \mathrm{O}$. This hydrophilic property has proven to contribute to the water uptake of membrane, and thus may result in dimensional instability of AEMs at an elevated temperature.

\subsection{AEM Prepared via Solution Casting with Crosslinker}

Covalent crosslinking is one of the effective techniques to solve the issue through: (1) bonding halomethyl groups with aromatic rings of neighboring polymer through a Friedel-Crafts reaction without external crosslinker, (2) bonding two functional groups on neighboring polymer lines together in the assistance of a micromolecular crosslinker, and (3) bonding two polymers together by the reaction between other groups and micromolecular crosslinker [25,42-46]. The aforementioned techniques on covalent crosslinking are not favorable due to their own limitations, which then leads to the proposal of a new route of covalent crosslinking by Lu et al. [46], using a macromolecule as crosslinker, and combines with the advantages of a semi-interpenetrated polymer network (semi-IPN) and crosslinking technique. The poly(vinyl acetal) (PVAc) was adopted as the macromolecular crosslinker to support the poly(vinylbenzyl chloride) (PVBC) through the interaction between quaternary ammonium (QA) groups and chloromethyl $(-\mathrm{CH} 2 \mathrm{Cl})$ groups. Although the hydrophilic nature of PVAc improved the conductivity performance and stability of the membrane at an elevated temperature, both excessive water uptake and swelling ratio will deteriorate the mechanical performance. Hence, a more hydrophobic polymer needs to be placed as the macromolecule crosslinker to suppress both water uptake and swelling ratio while forming the micro-phase separation of hydrophilic/hydrophobic polymers that assists in conducting the hydroxide. Xue et al. [47] have crosslinked PVBC with azidated poly(2,6-di-methyl-phenyleneoxide $\left(\mathrm{PPO}-\mathrm{N}_{3}\right)$ as shown in Figure 2. and resulted in 2-4 times higher tensile strength than those without crosslinked PVBC (15.8 MPa), yet with a comparable ion exchange capacity of 2.0 meq $\mathrm{g}^{-1}$ and an ionic conductivity of $3.5 \mathrm{mS} \mathrm{cm}^{-1}$.

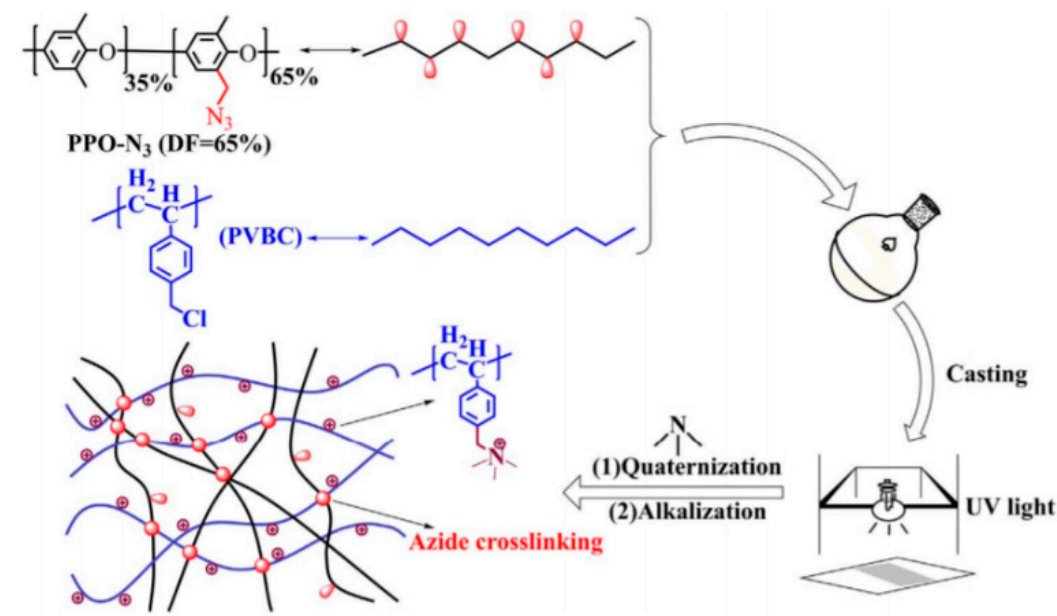

Figure 2. Crosslinking of PVBC-based AEMs with PPO- $\mathrm{N}_{3}$ by solution casting and UV irradiation methods. Reprinted with permission from [47]. Copyright Elsevier, 2017.

\subsection{AEM Composite Membranes Incorporated with Inorganic Fillers}

There are studies on the addition of inorganic components to the organic matrix of polymers such as titanium dioxide $\left(\mathrm{TiO}_{2}\right)$, zirconium dioxide $\left(\mathrm{ZrO}_{2}\right)$, aluminum oxide $\left(\mathrm{Al}_{2} \mathrm{O}_{3}\right)$, bentonite, and graphene oxide (GO) to improve the morphological stability of the membrane [27,48-52]. The addition of inorganic components reduces the glass transition temperature and increases the amorphous phases of the polymer matrix, which increases its ionic conductivity [71]. For instance, Nonjola et al. [27] added $\mathrm{TiO}_{2}$ filler into the quaternary polysulfone membrane, which has shown a reduction in membrane swelling and improve- 
ment in morphological stability without compromising ionic conductivity. The atomic force microscopy (AFM) revealed that addition of $\mathrm{TiO}_{2}$ increases the surface roughness of the membrane that prevents fuel crossover and subsequently increases the current efficiency. In another study, Ion-Ebrasu et al. [53] introduced graphene oxide into Fumion ${ }^{\circledR}$ and found that the modified composite membrane with the loading of $0.50 \mathrm{w} / \mathrm{v} \%$ graphene concentration increased the ionic conductivity to $113.27 \mathrm{mS} \mathrm{cm}^{-1}$ at $80{ }^{\circ} \mathrm{C}$, outperforming the as-received Fumion ${ }^{\circledR}$ that was thermally stable up to $60^{\circ} \mathrm{C}$ only. Movil et al. [33] have also shown that the incorporation of functionalized graphene oxide (FGO) into polyvinyl alcohol polydiallydimethylammonium chloride semi interpenetrating polymer networks (PVA/PDA/SIPNs) improve the $\mathrm{OH}^{-}$conductivity and thermo-mechanical stability under high relative humidity. However, the addition of inorganic components in excess into the polymer matrix may produce high numbers of pores, leading to a fragile structure and fuel crossover, and subsequently hindering the performance of the membrane.

\subsection{AEM Prepared via Pore-Filling Copolymerization Technique}

The pore-filling membrane fabrication technique can be used to fabricate low swelling AEMs. In general, polymer electrolytes are impregnated into a porous substrate or monomers are impregnated into a porous substrate, followed by polymerization [72,73]. Next, the volatile solvents are removed by evaporation to form the pore-filling AEM. This method leverages the advantages of both polymer (flexible and high ionic conductivity) and porous substrate (improved mechanical strength). Kim et al. [54] have fabricated novel pore-filled AEMs with polytetrafluoroethylene (PTFE) and poly $\left(N, N^{\prime}\right.$-dimethylaminoethyl methacrylate-DVB) (poly(DMAEMA-DVB)) copolymer. It was found that the combination of both structurally stable ion-exchange sites (i.e., poly(DMAEMA-DVB)) and highly hydrophobic PTFE has effectively lessened the degradation of quaternary alkyl ammonium. In another study, Kim et al. [55] also showed that the impregnation of quaternary PPO (QPPO) in porous PTFE could improve the dimensional properties and ionic conductivity of AEM (from $12.7 \mathrm{mS} \mathrm{cm}^{-1}$ to $33.1 \mathrm{mS} \mathrm{cm}^{-1}$ ). Yang et al. [72] have upscaled the production of pore-filling AEM using a roll-to-roll (R2R) process, as shown in Figure 3. The AEM, which was produced from this process, has an IEC and water uptake of $1.645 \mathrm{meq} \mathrm{g}^{-1}$ and $34.47 \%$, respectively. These properties are comparable to the commercial Fujifilm AEM that has an IEC and water uptake of $1.840 \mathrm{meq}^{-1}$ and $56.58 \%$, respectively.

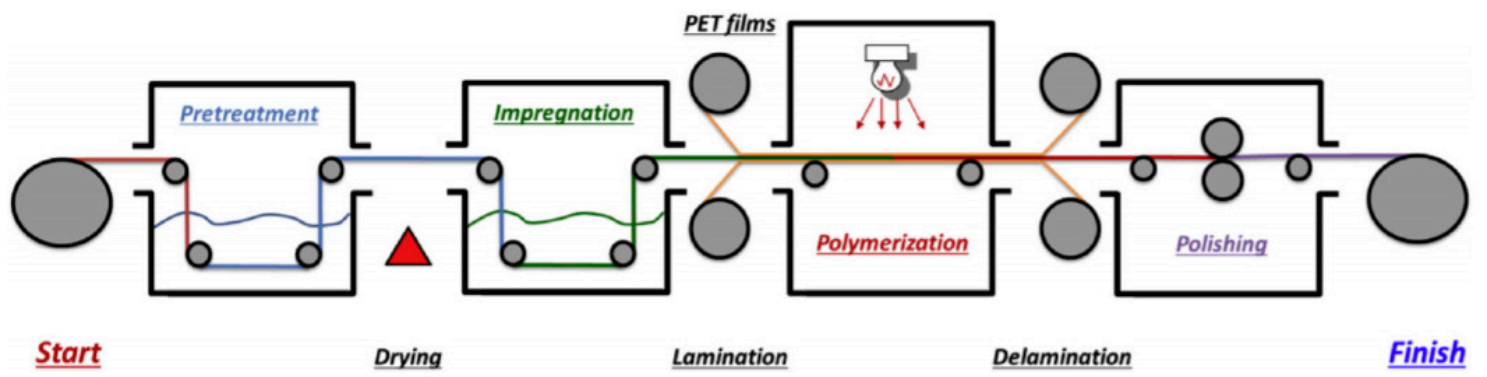

Figure 3. Schematic representation of the PAEM fabrication process using R2R equipment. Reprinted with permission from [72]. Copyright Elsevier, 2019.

\section{Design Consideration on Radiation-Grafted AEM}

The radiation-induced graft polymerization technique in fabricating AEMs is favorable because this technique is suitable for scale-up in industrial applications. Radiation has a strong penetrative power, which allows it to initiate the grafting process throughout the entire volume of polymer at relatively lower temperatures than the one with chemical initiators. The grafting penetration can also be adjusted accordingly to only functionalize the surface of polymers with the functional groups $-\mathrm{COOH},-\mathrm{OR},-\mathrm{OH},-\mathrm{NH}_{2},-\mathrm{SO}_{3} \mathrm{H},-\mathrm{R}$ and their derivatives, modifying the surface properties without affecting the properties of bulk material [74]. In comparison to the conventional grafting method, radiation-induced 
graft polymerization promotes more controllable graft copolymers with a predetermined molecular weight and polydispersity of grafted chains. Moreover, the radiation-induced grafting method is simple, relatively clean and reprocessable. This technique is also capable of modifying the polymeric surface with a wide range of shapes and properties without requiring the presence of a catalyst or initiators. Particularly, the modified surface likely free from any impurities related to functional moiety [74].

Due to the versatility of this technique, there are a few key parameters, including the selection of radiation source, polymer backbone, monomer concentration, type of solvents and additives, dose rate, total dose, grafting atmosphere and temperatures, that will influence the properties of the final product of AEMs. One of the important and unique properties of radiation-grafted membrane is the degree of grafting (D.O.G) [62,75], which is used to determine the amount of functional group that is successfully grafted onto the base polymer. The D.O.G can be estimated from Equation (7), whereby the percentage of mass changes the membrane before being grafted $\left(\mathrm{M}_{\mathrm{i}}\right)$ and after being grafted $\left(\mathrm{M}_{\mathrm{g}}\right)$.

$$
\text { D.O.G }(\%)=\frac{M_{g}(g)-M_{i}(g)}{M_{i}(g)} \times 100 \%
$$

The higher the irradiation dose, the higher the D.O.G with more available sites for the cation head groups to attach with [64]; however, a high irradiation dose also causes damage to the base polymer and reduces mechanical strength [76]. A membrane with low ionic exchange capacity usually results in low ionic conductivity, while if the membrane has a high ionic exchange capacity, it is usually associated with high water uptake, which in turn increases the swelling ratio that contributes to the mechanical stresses that eventually damages the membrane structure integrity [69]. A balance between these properties is essential for commercial adoption.

\subsection{Radiation Source}

The source of radiations can be from electromagnetic radiations such as gamma $(\gamma)$-ray, $\mathrm{X}$-ray, ultraviolet (UV), or charged particles such as electrons and beta particles [13,62]. The highly penetrative characteristic of radiation also allows it to introduce uniform and controllable active sites for grafting initiation, depending on the radiation species, dose rate, irradiation dose, properties of base polymer and monomer, as well as grafting environment. In addition, there are fewer shape and structure restrictions on the polymer matrix for radiation grafting, which enables it to be applied on preformed polymers without any postshaping issues [77]. The electron beam and gamma $(\gamma)$-ray are the two common sources used in radiation grafting. The electron beam is usually applied for the pre-irradiation method, where a high dose rate of electron beams is irradiated on the polymer backbone to produce free radicals. Meanwhile, gamma $(\gamma)$-ray is preferably applied in the simultaneous irradiation grating because it is the most penetrating of electromagnetic waves among the rest, but the grafting time is relatively longer than that of the electron beam [74]. However, gamma $(\gamma)$-ray offers much greater grafting efficiency by higher penetration [78]. Thus, the required grafting degrees are achievable at lower doses with gamma $(\gamma)$-ray in comparison to the electron beam. Furthermore, gamma $(\gamma)$-ray is more suitable for the preparation of grafted materials in large quantities for industrial enactment which relatively more economic, simpler, and robust. Irrespective of this, the selection of radiation source was still subjected to the targeted application and vital specification attached within the material functional scope. A membrane with a low ionic exchange capacity requires much lower grafting degrees merely on the surface of the polymeric materials. In these circumstances, the electron beam will be the most appropriate choice, as the penetration of electrons is considerably limited. While, contrastingly, gamma $(\gamma)$-ray fits well for the preparation of membrane with a high ionic exchange capacity for conferring higher grafting degrees. 


\subsection{Radiation Technique and Mechanism}

There are two common radiation-induced polymer grafting methods: (i) pre-irradiation grafting, either in an inert atmosphere or vacuum, or in the presence of air or oxygen, and (ii) simultaneous irradiation, as shown in Figure 4. The selection between these techniques is subjected to the radiation source, reactivity of monomer and the polymer to be modified.

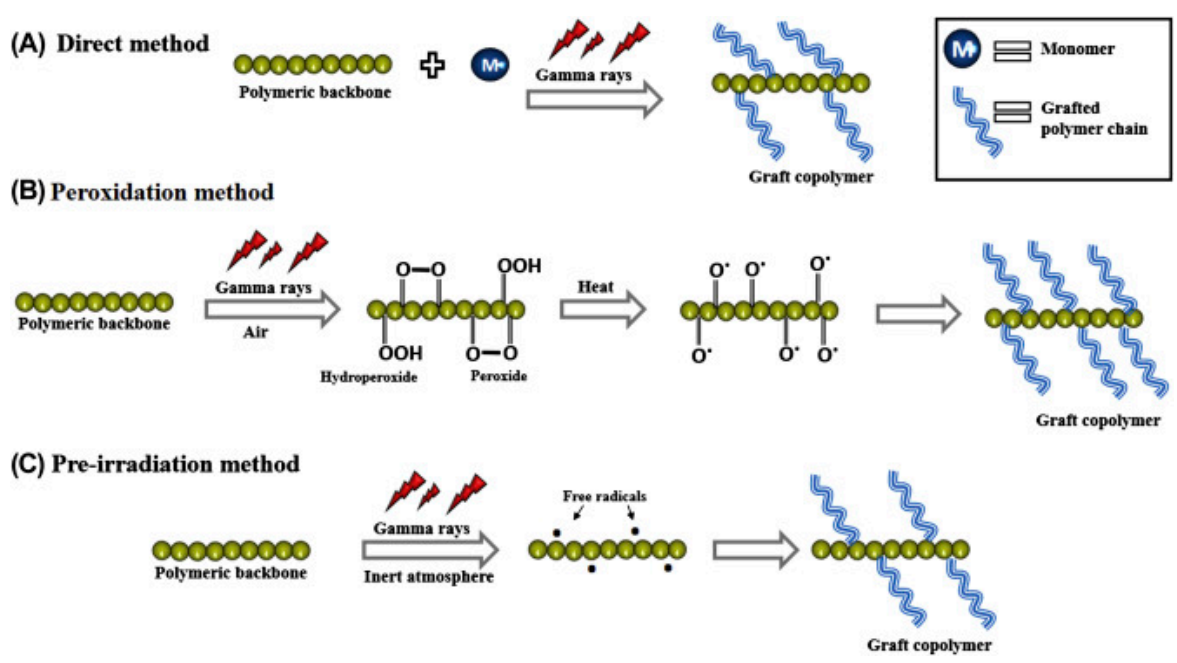

Figure 4. Schematic representation of the direct irradiation (A) and pre-irradiation methods $(\mathbf{B})$ with the presence of oxygen, also known as the peroxidation method, and (C) without the presence of oxygen. Reprinted with permission from [79]. Copyright Elsevier, 2018.

\subsubsection{Pre-Irradiation}

Pre-irradiation polymer backbone in an inert atmosphere or vacuum produces free radicals, which in turn act as a grafting site for the monomers. A high concentration of free radicals can be obtained with high-energy electron beams at a high dose rate, and grafting is performed instantaneously after the irradiation exposure [74]. In the presence of oxygen, the pre-irradiation of polymer backbone produces peroxides or hydroperoxides, which subsequently decompose into radicals at a higher temperature and initiate the grafting reaction upon interacting with monomers. The lifespan and stability of these radicals depend on the types of polymer backbone, as well as the storage conditions and durations, which permit the grafting process to be performed at a later time and away from the source of radiation $[67,80]$. The formation of homopolymer is in very minimal levels for this technique, as the activation of monomer by radiation is absent. Moreover, the degradation and crosslinking of the polymeric substrate are likely to take place during the course reaction, as the protection by monomer is missing as well. Besides, the efficiency of the grafting process is highly dependent on the radical lifetime of the polymer substrate [81]. Generally, the pre-irradiation method is suitable for production on a pilot scale.

\subsubsection{Simultaneous Irradiation Grafting}

In the simultaneous irradiation grafting method, both polymer backbone and monomers are irradiated simultaneously to produce free radicals. In principle, simultaneous irradiation is the simplest and most common grafting method to modify the polymer and is also appropriate for substrates sensitive to radiation. Undesirable effects of radiation degradation on the polymer matrix are greatly lessened by means of the protective effects from the monomers in the simultaneous irradiation grafting system. Furthermore, the greater number of radicals formed by irradiation on the polymer matrix in comparison to the one attained by the irradiation of monomers indicates an efficient grafting process. However, such a technique also leads to a higher chance of homo-polymerization and rapid deactivation of polymer backbone radicals due to recombination [82]. Simultaneous 
irradiation produces active sites in the polymer backbone, in the monomer and in the solvent, causing several unwanted side reactions that limit the degree of grafting and produce undesired homopolymers from the monomers. As such, this method requires inhibitors such as $\mathrm{Fe}^{2+}$ or $\mathrm{Cu}^{2+}$ or radical scavengers to suppress the formation of homopolymers. Hence, the choice of radiation technique depends on the characteristics of the polymer backbone and monomer and the scale of production.

\subsection{Selection of Polymer Backbone, Irradiation Dose and Dose Rate}

There are two categories of polymer backbone used in radiation-induced graft polymerization: fluorinated (or partially fluorinated) polymers and nonfluorinated polymers. Fluorinated polymers such as ethylene tetrafluoroethylene (ETFE) and Nafion®have been extensively used as polymer backbones owing to their favorable chemical and thermal stability. For instance, Fang et al. [43] grafted VBC onto poly(ethylene-co-tetrafluoroethylene) (ETFE) using $\gamma$-ray in argon with a total irradiation dose of $90 \mathrm{kGy}$, and functionalized with DABCO, DCX and TMA at various degrees of grafting (D.O.G). The highest ionic conductivity achieved was $74 \mathrm{mS} \mathrm{cm}{ }^{-1}$ at $80^{\circ} \mathrm{C}$. Ponce-González [83] studied the effect of the spacer groups on the alkaline stability of polymer. Butyl-spacer styrenic (labelled as C4-AEM) monomer and commercial VBC (labelled as C1-AEM) were grafted onto ETFE with an electron beam in air and aminated with MPY, respectively. They claimed that the IEC loss of C4-AEM after ageing in aqueous $\mathrm{KOH}\left(1 \mathrm{~mol} \mathrm{dm}^{-3}\right)$ at $80^{\circ} \mathrm{C}$ for 28 days was $13 \%$, approximately half of that of C1-AEM, which had an IEC loss of $27 \%$. The degradation of C4-AEM was predominantly contributed to by the loss of $\mathrm{Cl}^{-}$anions, but the $\mathrm{N}$ atoms were still retained on the polymer. Danks et al. [84] grafted VBC onto both polyvinylidene fluoride (PVDF) and fluorinated ethylene propylene (FEP), respectively. It was found that FEP-g-VBC membranes were thermally stable over a temperature range of 60 to $100{ }^{\circ} \mathrm{C}$, with approximately an $18 \%$ drop in IEC at $60{ }^{\circ} \mathrm{C}$ over a period of 119 days and possessed good ionic conductivity at room temperature (reported at $0.01-0.02 \mathrm{~S} \mathrm{~cm}^{-1}$ ). Meanwhile, the PVDF-g-VBC membrane was unstable because the PVDF backbone degraded upon amination and alkaline treatment. Poynton et al. [70] have also grafted VBC onto ETFE membrane (ETFE-g-VBC) for AEMFC applications, and the membrane has

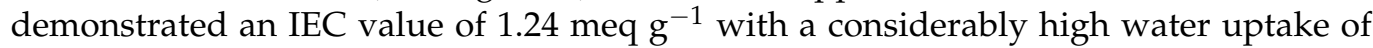
$155.4 \%$. Despite the fact that high water uptake was reported, it may not necessarily be detrimental to the AEMFC performance, because water is of pivotal importance for ion conduction. The performance of ETFE-g-VBC was promising, with a peak power density of $240 \mathrm{~mW} \mathrm{~cm}^{-2}$ in comparison to $180 \mathrm{~mW} \mathrm{~cm}^{-2}$ of the benchmark MEA under identical conditions. The high water uptake of AEMs produced via radiation grafting was also confirmed by Horsfall et al. [85]. The reaction of radiation grafting promotes a high degree of grafting (D.O.G) on the membrane, which in turn facilitates a greater percentage of water uptake.

Yoshimura et al. [65] have attempted to improve the alkaline stability of fluorinated polymer backbone by preventing the degradation of the imidazolium group caused by $\beta$-elimination and ring-opening hydrolysis reactions. They have grafted both hydrophobic styrene (St) and imidazolium containing methyl group (2-methyl- $N$-vinylimidazole (MNVIm)) onto ETFE (MNVIm/St-AEM) in argon atmosphere at room temperature, using a ${ }^{60} \mathrm{Co} \gamma$-ray source with a total irradiation dose of $80 \mathrm{kGy}$. The MNVIm/St-AEM was converted into terpolymergrafted membrane (MNVIm/En/St-AEM) upon treatment with 1 $\mathrm{M} \mathrm{KOH}$ at $80^{\circ} \mathrm{C}$, where an ethene monomer (En) was introduced between St monomer and MNVIm monomer that is bonded to the ETFE. The ionic conductivity of MNVIm/En/StAEM reduced drastically from $251 \mathrm{mS} \mathrm{cm}{ }^{-1}$ (MNVIm/St-AEM) to $53 \mathrm{mS} \mathrm{cm}^{-1}$ but maintaining a similar swelling ratio of $23 \%$. The alkaline stability of MNVIm/En/St-AEM was tested in $1 \mathrm{M} \mathrm{KOH}$ at $80^{\circ} \mathrm{C}$ and its ionic conductivity was recorded. The addition of methyl protecting group (i.e., MNVIm) has shown enhancement in alkaline stability, with an ionic conductivity higher than $10 \mathrm{mS} \mathrm{cm}^{-1}$ at $800 \mathrm{~h}$. To further understand the ionic conductivity channels of AEM in the presence of water [86], Yoshimura et al. $[87,88]$ used the small-angle 
X-ray scattering technique (SAXS) to investigate the ionic conducting structure of AEMs grafted with 2-methyl- $N$-vinulimidazolium and styrene groups at different degrees of grafting under various relative humidity $(\mathrm{RH})$ conditions. SAXS revealed that the mean distance between two ionic clusters was approximately $1.0 \mathrm{~nm}$ and the ionic conducting channels were disconnected at relative humidity $(\mathrm{RH})<80 \%$. While in water, the ionic conductivity of these AEMs increased significantly because the ionic conducting channels were well connected. This structural model explained the reason why most power generation of AEMFC reported to date is low because the reduction reaction of water at the cathode will reduce the RH significantly, thus decreasing the ionic conductivity. Kimura et al. [89] used SAXS to investigate the morphology changes of quaternized poly(arylene ether) semiblock co-polymer in relation to $\mathrm{RH}$ at $40^{\circ} \mathrm{C}$. SAXS results showed that the peak intensity increased with humidity and a Porod's slope of 4, as shown in Figure 5a, indicating that the periodic structure of hydrophilic domains in the AEM became more pronounced and the hydrophilic domains are in the form of a spherical shape, respectively. The SAXS shape analysis was consistent with the TEM results in Figure 5b.

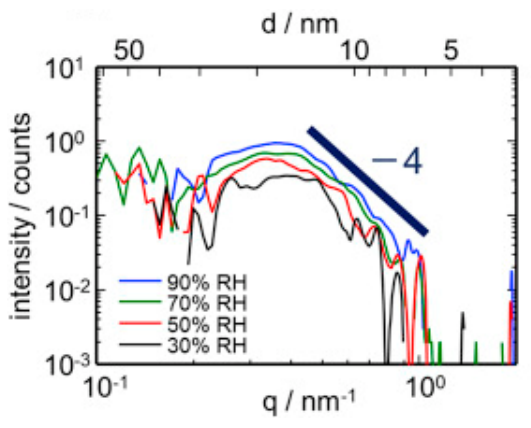

(a)
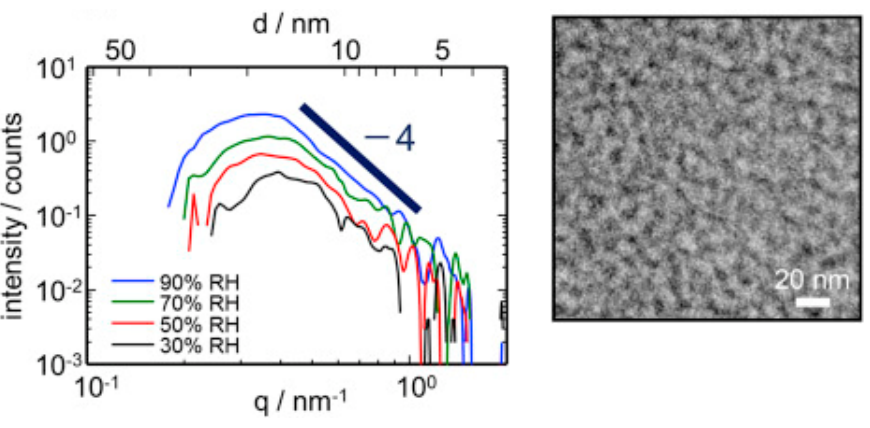

(b)

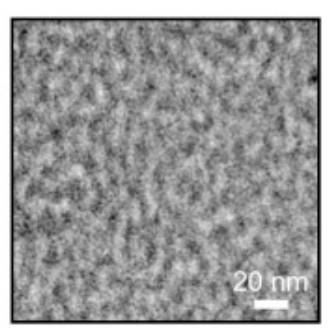

Figure 5. (a) Spherically shaped SAXS profile with a Porod's slope of 4 and (b) its corresponding TEM image. Reprinted with permission from [89]. Copyright Elsevier, 2018.

Building on the understanding of their previous work [65], Zhao et al. [90] have grafted imidazolium groups with St groups attached in perpendicular orientations onto ETFE (StIm-ETFE), with a total dose of $50 \mathrm{kGy}$ at a dose rate of $10 \mathrm{kGy} \mathrm{h}^{-1}$, using $\gamma$-ray. This molecular design prevents the $\beta$-elimination reaction and hydrolysis of imidazolium ring, hence further improving the alkaline durability of ETFE. The grafting time was varied from 40 to $960 \mathrm{~min}$ to control the D.O.G. They found that StIm-ETFE with a D.O.G of $18 \%$ at 72 min exhibited an ion exchange capacity of $0.54 \mathrm{mmolg}^{-1}$ and ionic conductivity of $>50 \mathrm{mS} \mathrm{cm}^{-1}$ at a significantly low water uptake $(\sim 10 \%)$. The StIm-ETFE membrane showed no sign of degradation over $600 \mathrm{~h}$ in $1 \mathrm{M} \mathrm{KOH}$ solution at $80^{\circ} \mathrm{C}$, maintaining its ionic conductivity of $50-60 \mathrm{mS} \mathrm{cm}^{-1}$. They have also found that there was a critical ion exchange capacity $\left(\mathrm{IEC}_{\mathrm{c}}\right.$ ) point in the range of 0.7 to $0.8 \mathrm{mmol} \mathrm{g}^{-1}$, where above this $\mathrm{IEC}_{\mathrm{c}}$ point, water uptake increased rapidly, contributed to by the switching of "reverse micelles" with water domains dispersed in the polymer matrix to "micelles" with graft polymer aggregates dispersed in the water matrix. Zhao et al. [91] also discovered that the ionic channels were microstructurally different depending on if imidazolium and styrene units were grafted parallelly (AEM1) or perpendicularly (AEM2) onto the ETFE membrane, respectively. The small-angle neutron scattering (SANS) with contrast variation method takes advantage of the inherent difference in scattering density properties between hydrogen and deuterium [92]. Upon hydration in heavy water $\left(\mathrm{D}_{2} \mathrm{O}\right)$, the hydrophilic ionic groups form ionic channels provide pathways to transport anion, while the hydrophobic ETFE polymer matrix maintains the membrane integrity by restricting the swelling. SANS revealed that both AEMs have a lamellar structure with alternate stacking between grafted polymer layers and crystalline ETFE layers, as shown in Figure 6. Nevertheless, the ionic channels of these AEMs were distinct from one another. AEM1 shows homogenous distributed 
ions in the ion channels, whereas AEM2 forms ionic clusters (caused by nanophase separation) with a size of $\sim 2.2 \mathrm{~nm}$, which improve the water diffusion and ionic conductivity of the membrane.

(a) AEM1

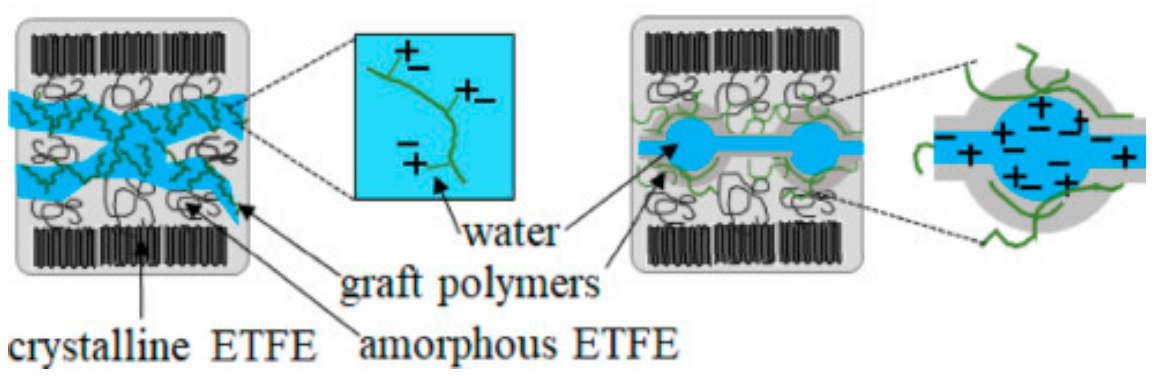

Figure 6. Schematic representation of ion channels of (a) parallel-grafted (AEM1) and (b) perpendicular-grafted (AEM2) ionic polymer into the ETFE polymer matrix. Reprinted with permission from [91]. Copyright Elsevier, 2018.

Nonetheless, high irradiation doses may cause damage to the fluorinated polymer main chains, such as ETFE-based AEMs, leading to mechanical weakening [76]. As such, Wang et al. [70] have attempted to optimize the irradiation process by replacing propan2-ol diluent with water, and further reduced the irradiation dose from 70 to $30 \mathrm{kGy}$, and VBC concentration from $20 \mathrm{vol} \%$ to $5 \mathrm{vol} \%$. The results showed that ETFE-g-VBC with reduced irradiation dose preserved its high IEC of $2.01 \mathrm{mmol} \mathrm{g}^{-1}$ and improved mechanical properties with its Young's modulus of $415 \mathrm{MPa}$, stress at break of $30 \%$ and elongation at break of $189 \%$, which were higher than the one irradiated at $70 \mathrm{kGy}$. The peak power density of AEMFC with ETFE-g-VBC membrane was reported at $1.16 \mathrm{~W} \mathrm{~cm}^{-2}$ at $60{ }^{\circ} \mathrm{C}$.

Non-fluorinated polymers, with a higher resistance to radiation damage, such as polyethylene (PE), low-density polyethylene (LDPE) and high-density polyethylene (HDPE)based anion exchange membranes, were proposed as an alternative to EFTE. These nonfluorinated hydrocarbon-based polymers offer several advantages over the fluorinated polymer, such as lower costs, enhanced commercial precursor availability, and more possibilities for recycling the final products (no C-F content) [76]. LDPE-based AEM offers a cheaper alternative to other commercially available materials [64], with promising thermomechanical and chemical stability, as well as durability properties. Faraj et al. [93] studied UV-induced grafting of VBC onto LDPE and aminated with 1,4-diazabicyclo(2.2.2)octane (LDPE-g-VBC-DABCO) for electrolysis cell applications. Here, DABCO also functions as cationic crosslinker, which supports the formation of thin sheet anion exchange thermoplastic membrane. Although DABCO contains b-hydrogen atoms, DABCO is highly resistant to alkali degradation through Hofmann elimination because of its rigid cage structure [94]. The LDPE-g-VBC-DABCO membrane was examined in terms of its ionic conductivity, ion exchange capacity, water uptake, electrolytic cell tests, and hydrogen permeability. They found that the electrochemical performance of LDPE-g-VBC-DABCO was comparable with the benchmark commercial membrane at that time, and the electrolysis cell with this membrane was able to produce approximately $30 \mathrm{cc} / \mathrm{min}$ of hydrogen at 20 bar, over more than $500 \mathrm{~h}$. It showed that the hydrogen permeation rate of LDPE-gVBC-DABCO, which was a safety concern in electrolysis applications, was in the range of $10^{-13} \mathrm{~mol} \mathrm{~cm}^{-1} \mathrm{~s}^{-1} \mathrm{kPa}^{-1}$. However, the LDPE-g-VBC-DABCO membrane displayed instability due to its low resistance in an alkaline environment. Wang et al. [76] compared the performance of radiation-grafted ETFE-based AEM and LDPE-based AEM. The LDPEbased AEM was able to withstand an irradiation dose of up to $100 \mathrm{kGy}$ without showing mechanical failure, while only an irradiation dose of $30 \mathrm{kGy}$ was used in ETFE-based AEM. It was found that that the $\mathrm{Cl}^{-}$conductivity of radiation-grafted LDPE-based AEM 
(76 $\mathrm{mS} \mathrm{cm}^{-1}$ at $80^{\circ} \mathrm{C}$ ) was slightly higher than that of ETFE-based AEM $\left(60 \mathrm{mS} \mathrm{cm}^{-1}\right.$ at $80^{\circ} \mathrm{C}$ ). However, the elasticity of LDPE-AEM after aging in alkaline at $80^{\circ} \mathrm{C}$ improved drastically, with the elongation at break of LDPE-based AEM at least an order larger than that of ETFE-based AEM. Similarly, Meek et al. [95] have studied the alkaline stability of radiation-grafted LDPE-based AEM at temperatures above $60^{\circ} \mathrm{C}$. The LDPE-based AEMs were subjected to a $4.5 \mathrm{MeV}$ electron beam irradiation at a dose of $100 \mathrm{kGy}$ in air and subsequently grafted with vinylbenzyl chloride (VBC) and aminated with trimethylamine (TMA), $N$-methylpyrolidine (MPY) and N-methylpiperidine (MPIP) head groups, respectively. They found that TMA-type LDPE-based AEM has the highest $\mathrm{Cl}^{-}$ionic conductivity $\left(100 \mathrm{mS} \mathrm{cm}{ }^{-1}\right.$ at $\left.80^{\circ} \mathrm{C}\right)$ and lowest alkaline degradation compared to the other two types. LDPE-g-VBC-TMA fabricated via the simultaneous irradiation technique using $\gamma$-ray in $\mathrm{N}_{2}$ saturated solution at a dose rate of $2 \mathrm{kGy} \mathrm{h}^{-1}$ and a total radiation dose of $20 \mathrm{kGy}$ by Gupta et al. [69,96] also showed a similar ionic conductivity of $90 \mathrm{mS} \mathrm{cm}^{-1}$ at $50{ }^{\circ} \mathrm{C}$.

While LDPE-based AEM has superior ionic conductivity and fast water transport kinetics, it is still prone to environmental stress cracking, particularly in the long-term operation of fuel cells and electrolysis cells. Limited by the membrane thickness for a fuel cell and electrolysis cell, Wang et al. [63] have proposed to replace the LDPE-based AEM with high-density polyethylene-based AEM (HDPE-based AEM) to enhance the mechanical properties of AEM. They have produced HDPE-based AEM using a $4.5 \mathrm{MeV}$ dynamic continuous electron beam at a high dose rate electron beam of $100 \mathrm{kGy}$ in air. The HDPE-based AEM was then grafted with VBC saturated in $\mathrm{N}_{2}$ for $4 \mathrm{~h}$ at $50^{\circ} \mathrm{C}$. This HPDE RG-AEM showed an enhancement in tensile properties (52\% higher than that of LDPE), fuel cell performance (voltage degradation up to $7 \%$ ) and operational stability (400 h of continues operation), yet with a comparable ionic conductivity $\left(\sim 214 \mathrm{mS} \mathrm{cm}^{-1}\right.$ ), ionic exchange capacity $\left(\sim 2.44 \mathrm{mmol} \mathrm{g}^{-1}\right)$ and water uptake ( 155\%) properties to LDPEbased AEM, which is contributed to by the changes in nanomorphology that improved the water transport mechanism after radiation grafting. Apart from HPDE, ultra-high molecular weight polyethylene (UHMWPE) is another class of low-cost and extremely tough polyethylene that can be used as the base polymer. Sherazi et al. [67] grafted VBC onto UHMWPE powder with $\gamma$-ray, which is subsequently compressed into thin AEM membrane and quaternized with TMA (UHMWPE-g-VBC-TMA). The highest ionic conductivity obtained in this investigation was $47.5 \mathrm{mS} \mathrm{cm}^{-1}$ at $90^{\circ} \mathrm{C}$, which was much lower than that of LDPE-based and HDPE-based AEMs discussed above. However, its ionic exchange capacity was notably constant $\left(\sim 0.58 \mathrm{meq} \mathrm{mol} \mathrm{g}^{-1}\right)$, even after $120 \mathrm{~h}$ of submersion in $10 \mathrm{M} \mathrm{NaOH}$ at $60^{\circ} \mathrm{C}$. Later, Sherazi et al. [68] quaternized UHMWPE-gVBC with modified guanidine, 1,1,3,3-tetramethyl-2-n-butylguanidine (UHMWPE-g-VBCTMBG). The IEC values increased with the total irradiation dose, with the highest IEC obtained for this membrane being 0.56 meq g $^{-1}$ with a total irradiation dose of $25 \mathrm{kGy}$. This trend agreed with other studies. However, they also observed that the maximum ionic conductivity was achieved at $27.7 \mathrm{mS} \mathrm{cm}^{-1}$ at $90^{\circ} \mathrm{C}$ with a total irradiation dose of $5 \mathrm{kGy}$. Beyond this point of irradiation dose, the ionic conductivity of the membrane decreased, which may be attributed to the excessive phase separation that disrupts the connectivity of ion conduction channels, resulting in higher resistivity.

Espiritu et al. [64] grafted VBC onto various sources of polyethylene, consisting of casting membranes of both low-density polyethylene (cast-LDPE) and linear low-density polyethylene (cast-LLDPE) from pellets supplied by Sigma Aldrich, and commercial membrane films from British Polyethene Industri plc (BPI-LDPE), VMR International (VMR-LDPE), ENTEK microporous (ENTEK-UHMWPE), using $\gamma$-ray with a dose rate of $2 \mathrm{kGy} \mathrm{h}^{-1}$, and functionalized with TMA. They reported that an increase in total irradiation dose from 10 to $20 \mathrm{kGy}$ resulted in an increase in D.O.G. of all the polyethylene membrane because more active sites were formed for VBC monomers to graft onto the polyethylene backbone. The BPI-LDPE-g-VBC membrane showed the highest value of IEC $\left(3.2 \mathrm{meq}^{-1}\right)$ and D.O.G (74.6\%) among the listed polyethylene membranes, respectively. The membrane also showed an extremely stable ionic conductivity of $0.11 \mathrm{~S} \mathrm{~cm}^{-1}$ in a 
durability test over a period of 7 months under nitrogen at $80{ }^{\circ} \mathrm{C}$. The AEMFC based on the BPI-LDPE-g-VBC membrane has demonstrated a peak power density of $608 \mathrm{~mW} \mathrm{~cm}{ }^{-2}$ at $50{ }^{\circ} \mathrm{C}$, with low fuel crossover. In another study, Espiritu et al. [75] investigated the effect of irradiation dose rate on the degradation of radiation-grafted VBC onto polyethylene-based (LDPE and HDPE) and EFTE-based AEMs and functionalized with TMA, respectively. The polyethylene-based membranes were both prepare via simultaneous irradiation with $\gamma$-ray with dose rate ranges from 30 to $2000 \mathrm{kGy} \mathrm{h}^{-1}$, while ETFE-based membrane was pre-irradiated with electron beam at a dose rate of $400 \mathrm{kGy} \mathrm{h}^{-1}$. Interestingly, they found that AEMs, regardless of fluorinated or non-fluorinated polymer backbone, that were treated with a high irradiation dose rate (above $400 \mathrm{kGy} \mathrm{h}^{-1}$ ) resulted in a lower loss of IEC (less than 15\%) in percentage over a period of 2 months compared to those treated at a low irradiation dose rate (up to $50 \%$ loss of IEC). They concluded that polymer subjected to high irradiation dose rate exhausts available oxygen rapidly and prevents any dissolved oxygen from penetrating into the polymer that degrades the polymer through oxidation. Table 2 summarizes and compares the performance of polyethylene-based and ETFE-based AEMs at different irradiation doses and dose rates.

Table 2. Properties of anion exchange membrane (AEM) at a different irradiation dose and dose rate.

\begin{tabular}{|c|c|c|c|c|c|c|c|c|}
\hline AEM & $\begin{array}{c}\text { Irradiation } \\
\text { Dose/Dose } \\
\text { Rate (kGy/Gy } \\
\left.\mathbf{h}^{-1}\right)\end{array}$ & D.O.G (\%) & $\begin{array}{c}\text { Water } \\
\text { Uptake (\%) }\end{array}$ & $\begin{array}{c}\text { Tensile } \\
\text { Strength } \\
\text { (MPa) }\end{array}$ & $\begin{array}{c}\text { IEC } \\
\left(\text { meq }^{-1}\right)\end{array}$ & $\begin{array}{l}\text { Ionic Con- } \\
\text { ductivity } \\
\left(\mathrm{mS} \mathrm{cm}^{-1}\right)\end{array}$ & $\begin{array}{c}\text { Cell } \\
\text { Performance } \\
\left(\mathrm{mW} \mathrm{cm}^{-2}\right)\end{array}$ & Ref. \\
\hline StIm-ETFE & $\begin{array}{l}\text { Dose: } 50 \\
\text { Grafting time: } \\
40 \text { to } 72 \mathrm{~min}\end{array}$ & 8 to 18 & 5 to 10 & - & 0.26 to 0.54 & $\begin{array}{c}17 \text { to } 50 \text { (at } \\
\left.60^{\circ} \mathrm{C}\right)\end{array}$ & - & [90] \\
\hline $\begin{array}{l}\text { BPI-LDPE-g- } \\
\text { VBC }\end{array}$ & Dose: 10 to 20 & 50.4 to 74.6 & 285 & - & 2.4 to 3.2 & $\begin{array}{l}90 \text { to } 110 \\
\text { (at } 60^{\circ} \mathrm{C} \text { ) }\end{array}$ & $608\left(\right.$ at $\left.50^{\circ} \mathrm{C}\right)$ & {$[64]$} \\
\hline ETFE-g-VBC & Dose: 40 to 30 & 89 to 76 & 57 to 53 & 262 to 416 & 2.13 to 2.01 & $\begin{array}{c}68 \text { to } 60 \text { (at } \\
\left.80^{\circ} \mathrm{C}\right)\end{array}$ & $\begin{array}{c}1160(\text { at } \\
\left.60^{\circ} \mathrm{C}\right)\end{array}$ & [70] \\
\hline $\begin{array}{c}\text { LDPE-based } \\
\text { AEM }\end{array}$ & Dose: 50 to 100 & 102 to 143 & 97 to 104 & 275 & 2.63 to 2.87 & 64 to 76 & $\begin{array}{c}1450 \text { (at } \\
\left.80^{\circ} \mathrm{C}\right)\end{array}$ & [76] \\
\hline $\begin{array}{l}\text { UHMWPE-g- } \\
\text { VBC-TMBG }\end{array}$ & Dose: 3 to 5 & 8.5 to 12.5 & 3.25 to 4.5 & - & 0.22 to 0.33 & $\begin{array}{c}14.4 \text { to } 27.7 \\
\left(\text { at } 90{ }^{\circ} \mathrm{C}\right)\end{array}$ & - & [68] \\
\hline $\begin{array}{c}\text { LDPE-g-VBC- } \\
\text { TMA }\end{array}$ & $\begin{array}{c}\text { Dose rate: } 67 \text { to } \\
2000\end{array}$ & 68 to 65 & - & - & 2.8 to 2.7 & $\begin{array}{c}84 \text { to } 99 \text { (at } \\
\left.60^{\circ} \mathrm{C}\right)\end{array}$ & - & [75] \\
\hline $\begin{array}{c}\text { HDPE-g-VBC- } \\
\text { TMA }\end{array}$ & $\begin{array}{l}\text { Dose rate: } 35 \text { to } \\
67\end{array}$ & 58 to 66 & - & - & 2.6 to 2.9 & $\begin{array}{l}84 \text { to } 101 \\
\text { (at } 60^{\circ} \mathrm{C} \text { ) }\end{array}$ & - & [75] \\
\hline
\end{tabular}

In 1996, Shell commercialized a type of aliphatic polyketone (PK), which is a terpolymer of carbon monoxide, ethylene and propylene. This relatively new type of polymer has excellent thermomechanical properties, high chemical stability and high resistance to hydrolysis. Nevertheless, its unique chemical resistance property also contributes to its difficulty to graft chemically. Kim et al. [97] are among the first group that used $\gamma$-irradiation to graft VBC onto PK membrane and aminated with TMA (PK-g-VBC-TMA). They have successfully achieved a D.O.G of $98 \%$ with a VBC monomer concentration of $70 \mathrm{wt} \%$ and at the total irradiation dose of $70 \mathrm{kGy}$. They found that the performance of PK-g-VBC-TMA outperformed a Nafion 117, which has an ionic conductivity of $78 \mathrm{mS} \mathrm{cm}^{-1}$, an IEC of $0.8 \mathrm{meq} \mathrm{g}^{-1}$, water uptake of $24 \%$ and swelling ratio of $21 \%$. Both ionic conductivity and the IEC of PK-g-VBC-TMA were recorded as $310 \mathrm{mS} \mathrm{cm}^{-1}$ and $1.2 \mathrm{meq} \mathrm{g}^{-1}$, respectively, which was supported by its maximum water uptake of $35 \%$. Although its water uptake was much higher than that of Nafion, the swelling ratio of PK-g-VBC-TMA was comparable to that of Nafion, which indicated that the mechanical strength of PK-g-VBC-TMA has a high potential for commercial applications. 
Recently, Samiego et al. [13] selected the biodegradable cellulose acetate (CA)-based polymer as the backbone for the first time because it is low-cost and environmentally benign. The use of natural polymers as a base for AEM in fuel cell and electrolysis cell applications offers a green alternative to modern energy production. The CA polymer was grafted with VBC and functionalized with TMA, using $\gamma$-ray at an irradiation dose of $40 \mathrm{kGy}$. An average ionic conductivity of up to $163 \mathrm{mS} \mathrm{cm}^{-1}$ at $40{ }^{\circ} \mathrm{C}$ was achieved; however, the performance of the CA-g-VBC-TMA membrane deteriorated drastically beyond $60^{\circ} \mathrm{C}$ due to excessive water uptake. By reducing the total irradiation dose treatment to $25 \mathrm{kGy}$, CA-g-VB-TMA membrane was able to operate in up to $70^{\circ} \mathrm{C}$, with a maximum ionic conductivity of $93 \mathrm{mS} \mathrm{cm}^{-1}$. Apart from LDPE and HPDE, ultra-high molecular weight polyethylene (UHMWPE) is another class of low-cost and extremely tough polyethylene that can be used as the base polymer.

\section{Conclusions}

The development of AEM for AEMFC and AEMEC applications is still in its infancy stage. Conventional membrane fabrication methods such as solution casting, covalent crosslinking, filler inclusion and pore-filling have been used to produce AEMs. Compared to the conventional methods, the radiation-induced grafting technique has the advantages of simplicity, cost saving, energy efficiency and being green. In addition, this advanced membrane-processing technology is highly customizable, where the irradiation parameters such as radiation sources, rate, dose and environment can be adjusted to control the initiation and propagation velocity of the grafting process at the desired modification depth. Radiation-induced grafting enables the control of hydrophilic and hydrophobic domains to ensure good micro/nanophase separation in the AEM to facilitate high ionic conduction. Radiation grafting spacers onto base polymers also improves the chemical stability properties of AEMs. With the booming of the hydrogen economy and increasing demand of low-cost green hydrogen production, both AEMFC and AEMEC have gained substantial attention because of their potential to reduce the cost of power and hydrogen production, respectively. Although the durability of AEMs has remarkably improved over the years, the durability of AEMs remains the main challenge and requires further improvement to achieve commercial readiness.

Author Contributions: Conceptualization, K.L.L. and W.Y.W.; writing—original draft preparation, K.L.L., C.Y.W., S.S. and N.A.F.O.; writing-review and editing, K.L.L. and W.Y.W.; supervision, K.L.L., W.Y.W. and K.S.L.; project administration, K.L.L.; funding acquisition, K.L.L., K.S.L. and H.Y. All authors have read and agreed to the published version of the manuscript.

Funding: This work was supported by the Malaysia Ministry of Higher Education (FRGS/1/ 2018/STG01/UKM/02/15), Universiti Kebangsaan Malaysia (GUP-2018-041 and PP-SELFUEL-2020), International Atomic Energy Agency (R23130), the Ministry of Science and Technology of Taiwan (MOST-108-3116-F-005-002) and SATU Joint Research Scheme (NCHU6).

Institutional Review Board Statement: Not applicable.

Informed Consent Statement: Not applicable.

Data Availability Statement: Not applicable.

Acknowledgments: K.L. Lim also acknowledges the MEXT Nuclear Researcher Exchange fellowship (IR-A-6) to undertake training in radiation technology at Takasaki Advanced Radiation Research Institute, Quantum and Radiological Science and Technology (QST), Japan.

Conflicts of Interest: The authors declare no conflict of interest. The funders had no role in the design of the study; in the collection, analyses, or interpretation of data; in the writing of the manuscript, or in the decision to publish the results.

\section{References}

1. Wong, C.; Wong, W.; Ramya, K.; Khalid, M.; Loh, K.; Daud, W.; Lim, K.; Walvekar, R.; Kadhum, A. Additives in proton exchange membranes for low- and high-temperature fuel cell applications: A review. Int. J. Hydrogen Energy 2019, 44, 6116-6135. [CrossRef] 
2. Wong, C.Y.; Wong, W.Y.; Loh, K.S.; Daud, W.R.W.; Lim, K.L.; Khalid, M.; Walvekar, R. Development of Poly(Vinyl Alcohol)-Based Polymers as Proton Exchange Membranes and Challenges in Fuel Cell Application: A Review. Polym. Rev. 2020, 60, 171-202. [CrossRef]

3. Wong, C.Y.; Wong, W.Y.; Loh, K.S.; Daud, W.R.W.; Lim, K.L.; Walvekar, R.; Khalid, M.; Loh, K.S. Comparative Study on Water Uptake and Ionic Transport Properties of Pre- and Post Sulfonated Chitosan/PVA polymer Exchange Membrane. In Proceedings of the IOP Conference Series: Materials Science and Engineering, Kuala Lumpur, Malaysia, 13-14 August 2018; IOP Publishing: Bristol, UK, 2018; Volume 458, p. 012017.

4. Wong, C.Y.; Wong, W.Y.; Loh, K.S.; Khalid, M.; Daud, W.R.W.; Lim, K.L.; Walvekar, R. Influences of crosslinked carboxylic acid monomers on the proton conduction characteristics of chitosan/SPVA composite membranes. Polymers 2020, 203, 122782. [CrossRef]

5. Wong, C.; Wong, W.; Walvekar, R.; Loh, K.; Khalid, M.; Lim, K. Effect of deep eutectic solvent in proton conduction and thermal behaviour of chitosan-based membrane. J. Mol. Liq. 2018, 269, 675-683. [CrossRef]

6. Kordesch, K.; Cifrain, M. A comparison between the alkaline fuel cell (AFC) and the polymer electrolyte membrane (PEM) fuel cell. In Handbook of Fuel Cells; Wiley: Hoboken, NJ, USA, 2010.

7. USDOE. Multi-Year Research Development, and Demonstration Plan; United State Department of Energy: Washington, DC, USA, 2015.

8. Miller, H.A.; Bouzek, K.; Hnat, J.; Loos, S.; Bernäcker, C.I.; Weissgaerber, T.; Röntzsch, L.; Meier-Haack, J. Green hydrogen from anion exchange membrane water electrolysis: A review of recent developments in critical materials and operating conditions. Sustain. Energy Fuels 2020, 4, 2114-2133. [CrossRef]

9. Merle, G.; Wessling, M.; Nijmeijer, K. Anion exchange membranes for alkaline fuel cells: A review. J. Membr. Sci. 2011, 377, 1-35. [CrossRef]

10. Varcoe, J.R.; Kizewski, J.P.; Halepoto, D.M.; Poynton, S.D.; Slade, R.C.T.; Zhao, F. Fuel Cells Alkaline fuel cells I anion-exchange membranes. In Encyclopedia of Electrochemical Power Sources; Garche, J., Ed.; Elsevier: Amsterdam, The Netherlands, 2009; pp. 329-343.

11. Hagesteijn, K.F.L.; Jiang, S.; Ladewig, B.P. A review of the synthesis and characterization of anion exchange membranes. J. Mater Sci. 2018, 53, 11131-11150. [CrossRef]

12. Xu, F.; Su, Y.; Lin, B. Progress of Alkaline Anion Exchange Membranes for Fuel Cells: The Effects of Micro-Phase Separation. Front. Mater. 2020, 7, 7. [CrossRef]

13. Samaniego, A.J.; Arabelo, A.K.; Sarker, M.; Mojica, F.; Madrid, J.; Chuang, P.A.; Ocon, J.; Espiritu, R. Fabrication of cellulose acetate-based radiation grafted anion exchange membranes for fuel cell application. J. Appl. Polym. Sci. 2021, 138. [CrossRef]

14. Vincent, I.; Kruger, A.; Bessarabov, D. Development of efficient membrane electrode assembly for low cost hydrogen production by anion exchange membrane electrolysis. Int. J. Hydrogen Energy 2017, 42, 10752-10761. [CrossRef]

15. Arges, C.G.; Ramani, V.; Pintauro, P.N. Anion exchange membrane fuel cells. Electrochem. Soc. Interface 2010, 31-35. [CrossRef]

16. Zongqing, L.; Jianwu, L. Research on elimination of chloromethylation in preparation on anion-exchange. Desalination 1985, 56, 421-430. [CrossRef]

17. Khan, M.I.; Luque, R.; Akhtar, S.; Shaheen, A.; Mehmood, A.; Idress, S.; Buzdar, S.A.; Rehman, A.U. Design of Anion Exchange Membranes and Electrodialysis Studies for Water Desalination. Materials 2016, 9, 365. [CrossRef] [PubMed]

18. Maurya, S.; Shin, S.-H.; Kim, Y.; Moon, S.-H. A review on recent developments of anion exchange membranes for fuel cells and redox flow batteries. RSC Adv. 2015, 5, 37206-37230. [CrossRef]

19. Chen, Y.; Lin, Q.; Zheng, Y.; Yu, Y.; Chen, D. Densely quaternized anion exchange membranes synthesized from Ullmann coupling extension of ionic segments for vanadium redox flow batteries. Sci. China Mater. 2019, 62, 211-224. [CrossRef]

20. Tsai, T.-H.; Maes, A.M.; Vandiver, M.A.; Versek, C.; Seifert, S.; Tuominen, M.; Liberatore, M.W.; Herring, A.M.; Coughlin, E.B. Synthesis and structure-conductivity relationship of polystyrene-block -poly(vinyl benzyl trimethylammonium) for alkaline anion exchange membrane fuel cells. J. Polym. Sci. Part. B Polym. Phys. 2013, 51, 1751-1760. [CrossRef]

21. Kim, D.J.; Lee, B.-N.; Nam, S.Y. Synthesis and characterization of PEEK containing imidazole for anion exchange membrane fuel cell. Int. J. Hydrog. Energy 2017, 42, 23759-23767. [CrossRef]

22. Lin, B.; Qiu, L.; Qiu, B.; Peng, Y.; Yan, F. A Soluble and Conductive Polyfluorene Ionomer with Pendant Imidazolium Groups for Alkaline Fuel Cell Applications. Macromolecules 2011, 44, 9642-9649. [CrossRef]

23. Gu, F.; Dong, H.; Li, Y.; Sun, Z.; Yan, F. Base Stable Pyrrolidinium Cations for Alkaline Anion Exchange Membrane Applications Macromolecules 2014, 47, 6740-6747. [CrossRef]

24. Wang, J.; Li, S.; Zhang, S. Novel Hydroxide-Conducting Polyelectrolyte Composed of an Poly(arylene ether sulfone) Containing Pendant Quaternary Guanidinium Groups for Alkaline Fuel Cell Applications. Macromolecules 2010, 43, 3890-3896. [CrossRef]

25. Gu, S.; Cai, R.; Yan, Y. Self-crosslinking for dimensionally stable and solvent-resistant quaternary phosphonium based hydroxide exchange membranes. Chem. Commun. 2011, 47, 2856-2858. [CrossRef]

26. Stokes, K.K.; Orlicki, J.A.; Beyer, F.L. RAFT polymerization and thermal behavior of trimethylphosphonium polystyrenes for anion exchange membranes. Polym. Chem. 2010, 2, 80-82. [CrossRef]

27. Nonjola, P.T.; Mathe, M.; Modibedi, R.M. Chemical modification of polysulfone: Composite anionic exchange membrane with $\mathrm{TiO}_{2}$ nano-particles. Int. J. Hydrogen Energy 2013, 38, 5115-5121. [CrossRef] 
28. Chen, W.; Yan, X.; Wu, X.; Huang, S.; Luo, Y.; Gong, X.; He, G. Tri-quaternized poly (ether sulfone) anion exchange membranes with improved hydroxide conductivity. J. Membr. Sci. 2016, 514, 613-621. [CrossRef]

29. Kim, Y.; Moh, L.C.; Swager, T.M. Anion Exchange Membranes: Enhancement by Addition of Unfunctionalized Triptycene Poly(Ether Sulfone)s. ACS Appl. Mater. Interfaces 2017, 9, 42409-42414. [CrossRef] [PubMed]

30. Zheng, J.; Zhang, Q.; Qian, H.; Xue, B.; Li, S.; Zhang, S. Self-assembly prepared anion exchange membranes with high alkaline stability and organic solvent resistance. J. Membr. Sci. 2017, 522, 159-167. [CrossRef]

31. Hwang, G.-J.; Ohya, H. Preparation of anion-exchange membrane based on block copolymers part 1. Amination of the chloromethylated copolymers. J. Membr. Sci. 1998, 140, 195-203. [CrossRef]

32. Liu, L.; Tong, C.; He, Y.; Zhao, Y.; Lü, C. Enhanced properties of quaternized graphenes reinforced polysulfone based composite anion exchange membranes for alkaline fuel cell. J. Membr. Sci. 2015, 487, 99-108. [CrossRef]

33. Movil, O.; Frank, L.; Staser, J.A. Graphene Oxide-Polymer Nanocomposite Anion-Exchange Membranes. J. Electrochem. Soc. 2015, 162, F419-F426. [CrossRef]

34. Oh, B.H.; Kim, A.R.; Yoo, D.J. Profile of extended chemical stability and mechanical integrity and high hydroxide ion conductivity of poly(ether imide) based membranes for anion exchange membrane fuel cells. Int. J. Hydrogen Energy 2019, 44, 4281-4292. [CrossRef]

35. Parrondo, J.; Jung, M.-S.J.; Wang, Z.; Arges, C.G.; Ramani, V. Synthesis and Alkaline Stability of Solubilized Anion Exchange Membrane Binders Based on Poly(phenylene oxide) Functionalized with Quaternary Ammonium Groups via a Hexyl Spacer. J. Electrochem. Soc. 2015, 162, F1236-F1242. [CrossRef]

36. Zhu, Y.; Ding, L.; Liang, X.; Shehzad, M.A.; Wang, L.; Ge, X.; He, Y.; Wu, L.; Varcoe, J.R.; Xu, T. Beneficial use of rotatable-spacer side-chains in alkaline anion exchange membranes for fuel cells. Energy Environ. Sci. 2018, 11, 3472-3479. [CrossRef]

37. Chen, D.; Hickner, M.A. Degradation of Imidazolium- and Quaternary Ammonium-Functionalized Poly(fluorenyl ether ketone sulfone) Anion Exchange Membranes. ACS Appl. Mater. Interfaces 2012, 4, 5775-5781. [CrossRef]

38. Liu, L.; He, S.; Zhang, S.; Zhang, M.; Guiver, M.D.; Li, N. 1,2,3-Triazolium-Based Poly(2,6-Dimethyl Phenylene Oxide) Copolymers as Anion Exchange Membranes. ACS Appl. Mater. Interfaces 2016, 8, 4651-4660. [CrossRef] [PubMed]

39. Wang, X.; Li, M.; Golding, B.T.; Sadeghi, M.; Cao, Y.; Yu, E.H.; Scott, K. A polytetrafluoroethylene-quaternary 1,4-diazabicyclo[2.2.2]-octane polysulfone composite membrane for alkaline anion exchange membrane fuel cells. Int. J. Hydrogen Energy 2011, 36, 10022-10026. [CrossRef]

40. Pérez-Prior, M.T.; Ureña, N.; Tannenberg, M.; Del Río, C.; Levenfeld, B. DABCO-functionalized polysulfones as anion-exchange membranes for fuel cell applications: Effect of crosslinking. J. Polym. Sci. Part. B Polym. Phys. 2017, 55, 1326-1336. [CrossRef]

41. Wu, L.; Xu, T.; Wu, D.; Zheng, X. Preparation and characterization of CPPO/BPPO blend membranes for potential application in alkaline direct methanol fuel cell. J. Membr. Sci. 2008, 310, 577-585. [CrossRef]

42. Sun, H.; Zhang, G.; Liu, Z.; Zhang, N.; Zhang, L.; Ma, W.; Zhao, C.; Qi, D.; Li, G.; Na, H. Self-crosslinked alkaline electrolyte membranes based on quaternary ammonium poly (ether sulfone) for high-performance alkaline fuel cells. Int. J. Hydrogen Energy 2012, 37, 9873-9881. [CrossRef]

43. Fang, J.; Yang, Y.; Lu, X.; Ye, M.; Li, W.; Zhang, Y. Cross-linked, ETFE-derived and radiation grafted membranes for anion exchange membrane fuel cell applications. Int. J. Hydrog. Energy 2012, 37, 594-602. [CrossRef]

44. Komkova, E.; Stamatialis, D.; Strathmann, H.; Wessling, M. Anion-exchange membranes containing diamines: Preparation and stability in alkaline solution. J. Membr. Sci. 2004, 244, 25-34. [CrossRef]

45. Zhou, J.; Unlu, M.; Anestis-Richard, I.; Kohl, P.A. Crosslinked, epoxy-based anion conductive membranes for alkaline membrane fuel cells. J. Membr. Sci. 2010, 350, 286-292. [CrossRef]

46. Lu, W.; Shao, Z.-G.; Zhang, G.; Zhao, Y.; Yi, B. Crosslinked poly(vinylbenzyl chloride) with a macromolecular crosslinker for anion exchange membrane fuel cells. J. Power Sources 2014, 248, 905-914. [CrossRef]

47. Xue, J.; Liu, L.; Liao, J.; Shen, Y.; Li, N. UV-crosslinking of polystyrene anion exchange membranes by azidated macromolecular crosslinker for alkaline fuel cells. J. Membr. Sci. 2017, 535, 322-330. [CrossRef]

48. Vinodh, R.; Purushothaman, M.; Sangeetha, D. Novel quaternized polysulfone/ZrO2 composite membranes for solid alkaline fuel cell applications. Int. J. Hydrog. Energy 2011, 36, 7291-7302. [CrossRef]

49. Mohamad, A.A.; Arof, A. Plasticized alkaline solid polymer electrolyte system. Mater. Lett. 2007, 61, 3096-3099. [CrossRef]

50. Sang, S.; Zhang, J.; Wu, Q.; Liao, Y. Influences of Bentonite on conductivity of composite solid alkaline polymer electrolyte PVA-Bentonite-KOH-H2O. Electrochimica ACTA 2007, 52, 7315-7321. [CrossRef]

51. García-Cruz, L.; Casado-Coterillo, C.; Irabien, Á.; Montiel, V.; Iniesta, J. High Performance of Alkaline Anion-Exchange Membranes Based on Chitosan/Poly (vinyl) Alcohol Doped with Graphene Oxide for the Electrooxidation of Primary Alcohols. J. Carbon Res. 2016, 2, 10. [CrossRef]

52. Li, Y.; Shi, S.; Cao, H.; Zhao, Z.; Wen, H. Modification and properties characterization of heterogeneous anion-exchange membranes by electrodeposition of graphene oxide (GO). Appl. Surf. Sci. 2018, 442, 700-710. [CrossRef]

53. Ion-Ebrasu, D.; Pollet, B.G.; Caprarescu, S.; Chitu, A.; Trusca, R.; Niculescu, V.; Gabor, R.; Carcadea, E.; Varlam, M.; Vasile, B.S. Graphene inclusion effect on anion-exchange membranes properties for alkaline water electrolyzers. Int. J. Hydrogen Energy 2020, 45, 17057-17066. [CrossRef]

54. Kim, D.-H.; Park, J.-S.; Choun, M.; Lee, J.; Kang, M.-S. Pore-filled anion-exchange membranes for electrochemical energy conversion applications. Electrochim. ACTA 2016, 222, 212-220. [CrossRef] 
55. Kim, J.-H.; Ryu, S.; Maurya, S.; Lee, J.-Y.; Sung, K.-W.; Lee, J.-S.; Moon, S.-H. Fabrication of a composite anion exchange membrane with aligned ion channels for a high-performance non-aqueous vanadium redox flow battery. RSC Adv. 2020, 10, 5010-5025. [CrossRef]

56. Kim, D.-H.; Seo, S.-J.; Lee, M.-J.; Park, J.-S.; Moon, S.-H.; Kang, Y.S.; Choi, Y.-W.; Kang, M.-S. Pore-filled anion-exchange membranes for non-aqueous redox flow batteries with dual-metal-complex redox shuttles. J. Membr. Sci. 2014, 454, 44-50. [CrossRef]

57. Seo, S.-J.; Kim, B.-C.; Sung, K.-W.; Shim, J.; Jeon, J.-D.; Shin, K.-H.; Shin, S.-H.; Yun, S.-H.; Lee, J.-Y.; Moon, S.-H. Electrochemical properties of pore-filled anion exchange membranes and their ionic transport phenomena for vanadium redox flow battery applications. J. Membr. Sci. 2013, 428, 17-23. [CrossRef]

58. Liu, Y.; Zhou, J.; Hou, J.; Yang, Z.; Xu, T. Hyperbranched Polystyrene Copolymer Makes Superior Anion Exchange Membrane. ACS Appl. Polym. Mater. 2018, 1, 76-82. [CrossRef]

59. Buggy, N.C.; Du, Y.; Kuo, M.-C.; Ahrens, K.A.; Wilkinson, J.S.; Seifert, S.; Coughlin, E.B.; Herring, A.M. A Polyethylene-Based Triblock Copolymer Anion Exchange Membrane with High Conductivity and Practical Mechanical Properties. ACS Appl. Polym. Mater. 2020, 2, 1294-1303. [CrossRef]

60. Kim, J.H.; Vinothkannan, M.; Kim, A.R.; Yoo, D.J. Anion Exchange Membranes Obtained from Poly(arylene ether sulfone) Block Copolymers Comprising Hydrophilic and Hydrophobic Segments. Polymers 2020, 12, 325. [CrossRef]

61. Wang, J.; He, R. Formation and evaluation of interpenetrating networks of anion exchange membranes based on quaternized chitosan and copolymer poly(acrylamide)/polystyrene. Solid State Ion. 2015, 278, 49-57. [CrossRef]

62. Espiritu, R.; Golding, B.T.; Scott, K.; Mamlouk, M. Degradation of radiation grafted anion exchange membranes tethered with different amine functional groups via removal of vinylbenzyl trimethylammonium hydroxide. J. Power Sources 2018, 375, 373-386. [CrossRef]

63. Wang, L.; Peng, X.; Mustain, W.E.; Varcoe, J.R. Radiation-grafted anion-exchange membranes: The switch from low- to highdensity polyethylene leads to remarkably enhanced fuel cell performance. Energy Environ. Sci. 2019, 12, 1575-1579. [CrossRef]

64. Espiritu, R.; Mamlouk, M.; Scott, K. Study on the effect of the degree of grafting on the performance of polyethylene-based anion exchange membrane for fuel cell application. Int. J. Hydrogen Energy 2016, 41, 1120-1133. [CrossRef]

65. Yoshimura, K.; Hiroki, A.; Yu, H.-C.; Zhao, Y.; Shishitani, H.; Yamaguchi, S.; Tanaka, H.; Maekawa, Y. Alkaline durable 2methylimidazolium containing anion-conducting electrolyte membranes synthesized by radiation-induced grafting for direct hydrazine hydrate fuel cells. J. Membr. Sci. 2019, 573, 403-410. [CrossRef]

66. Poynton, S.D.; Slade, R.C.T.; Omasta, T.J.; Mustain, W.E.; Escudero-Cid, R.; Ocón, P.; Varcoe, J.R. Preparation of radiation-grafted powders for use as anion exchange ionomers in alkaline polymer electrolyte fuel cells. J. Mater. Chem. A 2014, 2, 5124-5130. [CrossRef]

67. Sherazi, T.A.; Sohn, J.Y.; Lee, Y.M.; Guiver, M.D. Polyethylene-based radiation grafted anion-exchange membranes for alkaline fuel cells. J. Membr. Sci. 2013, 441, 148-157. [CrossRef]

68. Sherazi, T.A.; Zahoor, S.; Raza, R.; Shaikh, A.; Naqvi, S.A.R.; Abbas, G.; Khan, Y.; Li, S. Guanidine functionalized radiation induced grafted anion-exchange membranes for solid alkaline fuel cells. Int. J. Hydrog. Energy 2015, 40, 786-796. [CrossRef]

69. Gupta, G.; Scott, K.; Mamlouk, M. Performance of polyethylene based radiation grafted anion exchange membrane with polystyrene-b-poly (ethylene/butylene)-b-polystyrene based ionomer using NiCo2O4 catalyst for water electrolysis. J. Power Sources 2018, 375, 387-396. [CrossRef]

70. Wang, L.; Magliocca, E.; Cunningham, E.L.; Mustain, W.E.; Poynton, S.D.; Escudero-Cid, R.; Nasef, M.M.; Ponce-González, J.; Bance-Souahli, R.; Slade, R.C.T.; et al. An optimised synthesis of high performance radiation-grafted anion-exchange membranes. Green Chem. 2017, 19, 831-843. [CrossRef]

71. Yang, C.-C.; Chiu, S.-J.; Lee, K.-T.; Chien, W.-C.; Lin, C.-T.; Huang, C.-A. Study of poly(vinyl alcohol)/titanium oxide composite polymer membranes and their application on alkaline direct alcohol fuel cell. J. Power Sources 2008, 184, 44-51. [CrossRef]

72. Yang, S.; Choi, Y.-W.; Choi, J.; Jeong, N.; Kim, H.; Jeong, H.; Byeon, S.Y.; Yoon, H.; Kim, Y.H. Green fabrication of pore-filling anion exchange membranes using R2R processing. J. Membr. Sci. 2019, 584, 181-190. [CrossRef]

73. Ran, J.; Wu, L.; He, Y.; Yang, Z.; Wang, Y.; Jiang, C.; Ge, L.; Bakangura, E.; Xu, T. Ion exchange membranes: New developments and applications. J. Membr. Sci. 2017, 522, 267-291. [CrossRef]

74. Walo, M. Radiation-induced Grafting. In Applications of Ionizing Radiation in Materials Processing; Sun, Y.C., Chmielewski, A.G., Eds.; Institute of Nuclear Chemistry and Technology: Warsaw, Poland, 2017; Volume 2, pp. 193-210.

75. Espiritu, R.; Golding, B.T.; Scott, K.; Mamlouk, M. Degradation of radiation grafted hydroxide anion exchange membrane immersed in neutral $\mathrm{pH}$ : Removal of vinylbenzyl trimethylammonium hydroxide due to oxidation. J. Mater. Chem. A 2016, 5, 1248-1267. [CrossRef]

76. Wang, L.; Brink, J.J.; Liu, Y.; Herring, A.M.; Ponce-González, J.; Whelligan, D.K.; Varcoe, J.R. Non-fluorinated pre-irradiationgrafted (peroxidated) LDPE-based anion-exchange membranes with high performance and stability. Energy Environ. Sci. 2017, 10, 2154-2167. [CrossRef]

77. Zhou, T.; Shao, R.; Chen, S.; He, X.; Qiao, J.; Zhang, J. A review of radiation-grafted polymer electrolyte membranes for alkaline polymer electrolyte membrane fuel cells. J. Power Sources 2015, 293, 946-975. [CrossRef]

78. Ashfaq, A.; Clochard, M.-C.; Coqueret, X.; Dispenza, C.; Driscoll, M.S.; Ulański, P.; Al-Sheikhly, M. Polymerization Reactions and Modifications of Polymers by Ionizing Radiation. Polymers 2020, 12, 2877. [CrossRef] 
79. Pino-Ramos, V.H.; Meléndez-Ortiz, H.I.; Ramos-Ballesteros, A.; Bucio, E. Chapter 6-Radiation Grafting of Biopolymers and Synthetic Polymers: Synthesis and Biomedical Applications. In Biopolymer Grafting; Thakur, V.K., Ed.; Elsevier: Amsterdam, The Netherlands, 2018.

80. Sherazi, T.A. Radiation-Induced Grafting. In Encyclopedia of Membranes; Drioli, E., Giorno, L., Eds.; Springer: Berlin, Heidelberg, 2015; pp. 1-2. [CrossRef]

81. Casimiro, M.H.; Ferreira, L.M.; Leal, J.P.; Pereira, C.C.L.; Monteiro, B. Ionizing Radiation for Preparation and Functionalization of Membranes and Their Biomedical and Environmental Applications. Membranes 2019, 9, 163. [CrossRef]

82. Nasef, M.M. Preparation and applications of ion exchange membranes by radiation-induced graft copolymerization of polar monomers onto non-polar films. Prog. Polym. Sci. 2004, 29, 499-561. [CrossRef]

83. Ponce-González, J.; Ouachan, I.; Varcoe, J.R.; Whelligan, D.K. Radiation-induced grafting of a butyl-spacer styrenic monomer onto ETFE: The synthesis of the most alkali stable radiation-grafted anion-exchange membrane to date. J. Mater. Chem. A 2017, 6, 823-827. [CrossRef]

84. Danks, T.N.; Slade, R.C.T.; Varcoe, J. Alkaline anion-exchange radiation-grafted membranes for possible electrochemical application in fuel cells. J. Mater. Chem. 2003, 13, 712-721. [CrossRef]

85. Horsfall, J.; Lovell, K. Fuel Cell Performance of Radiation Grafted Sulphonic Acid Membranes. Fuel Cells 2001, 1, 186-191. [CrossRef]

86. Pasquini, L.; Wacrenier, O.; Di Vona, M.L.; Knauth, P.C. Hydration and Ionic Conductivity of Model Cation and Anion-Conducting Ionomers in Buffer Solutions (Phosphate, Acetate, Citrate). J. Phys. Chem. B 2018, 122, 12009-12016. [CrossRef] [PubMed]

87. Yoshimura, K.; Zhao, Y.; Hasegawa, S.; Hiroki, A.; Kishiyama, Y.; Shishitani, H.; Yamaguchi, S.; Tanaka, H.; Koizumi, S.; Appavou, M.-S.; et al. Imidazolium-based anion exchange membranes for alkaline anion fuel cells: (2) elucidation of the ionic structure and its impact on conducting properties. Soft Matter 2017, 13, 8463-8473. [CrossRef]

88. Yoshimura, K.; Zhao, Y.; Hiroki, A.; Kishiyama, Y.; Shishitani, H.; Yamaguchi, S.; Tanaka, H.; Koizumi, S.; Houston, J.E.; Radulescu, A.; et al. Reverse relationships of water uptake and alkaline durability with hydrophilicity of imidazolium-based grafted anion-exchange membranes. Soft Matter 2018, 14, 9118-9131. [CrossRef]

89. Kimura, T.; Akiyama, R.; Miyatake, K.; Inukai, J. Phase separation and ion conductivity in the bulk and at the surface of anion exchange membranes with different ion exchange capacities at different humidities. J. Power Sources 2018, 375, 397-403. [CrossRef]

90. Zhao, Y.; Yoshimura, K.; Mahmoud, A.M.A.; Yu, H.-C.; Okushima, S.; Hiroki, A.; Kishiyama, Y.; Shishitani, H.; Yamaguchi, S.; Tanaka, H.; et al. A long side chain imidazolium-based graft-type anion-exchange membrane: Novel electrolyte and alkaline-durable properties and structural elucidation using SANS contrast variation. Soft Matter 2020, 16, 8128-8143. [CrossRef]

91. Zhao, Y.; Yoshimura, K.; Yu, H.-C.; Maekawa, Y.; Hiroki, A.; Kishiyama, Y.; Shishitani, H.; Yamaguchi, S.; Tanaka, H.; Koizumi, S.; et al. Small angle neutron scattering study on the morphology of imidazolium-based grafted anion-conducting fuel cell membranes. Phys. B Condens. Matter 2018, 551, 203-207. [CrossRef]

92. Otsuki, A.; De Campo, L.; Garvey, C.J.; Rehm, C. H2O/D2O Contrast Variation for Ultra-Small-Angle Neutron Scattering to Minimize Multiple Scattering Effects of Colloidal Particle Suspensions. Colloids Interfaces 2018, 2, 37. [CrossRef]

93. Faraj, M.; Boccia, M.; Miller, H.; Martini, F.; Borsacchi, S.; Geppi, M.; Pucci, A. New LDPE based anion-exchange membranes for alkaline solid polymeric electrolyte water electrolysis. Int. J. Hydrogen Energy 2012, 37, 14992-15002. [CrossRef]

94. Lu, W.; Zhang, G.; Li, J.; Hao, J.; Wei, F.; Li, W.; Zhang, J.; Shao, Z.-G.; Yi, B. Polybenzimidazole-crosslinked poly(vinylbenzyl chloride) with quaternary 1,4-diazabicyclo (2.2.2) octane groups as high-performance anion exchange membrane for fuel cells. J. Power Sources 2015, 296, 204-214. [CrossRef]

95. Meek, K.M.; Reed, C.M.; Pivovar, B.; Kreuer, K.-D.; Varcoe, J.R.; Bance-Soualhi, R. The alkali degradation of LDPE-based radiationgrafted anion-exchange membranes studied using different ex situ methods. RSC Adv. 2020, 10, 36467-36477. [CrossRef]

96. Gupta, G.; Scott, K.; Mamlouk, M. Soluble Polystyrene-b-poly (ethylene/butylene)-b-polystyrene Based Ionomer for Anion Exchange Membrane Fuel Cells Operating at $70^{\circ} \mathrm{C}$. Fuel Cells 2018, 18, 137-147. [CrossRef]

97. Kim, Y.J.; Hwang, C.W.; Hyeon, S.M.; Canlier, A.; Hwang, T.S. Synthesis of polyketone-g-vinylbenzyl chloride anion exchange membrane via irradiation and its properties. Macromol. Res. 2017, 25, 898-904. [CrossRef] 